Portland State University

PDXScholar

1990

\title{
A Study of Washington Secondary Principals' Perceptions of Effective Dropout Prevention Policies and Programs
}

Susan Lindsley Greenwood Portland State University

Follow this and additional works at: https://pdxscholar.library.pdx.edu/open_access_etds Let us know how access to this document benefits you.

\section{Recommended Citation}

Greenwood, Susan Lindsley, "A Study of Washington Secondary Principals' Perceptions of Effective Dropout Prevention Policies and Programs" (1990). Dissertations and Theses. Paper 1191.

https://doi.org/10.15760/etd.1190

This Dissertation is brought to you for free and open access. It has been accepted for inclusion in Dissertations and Theses by an authorized administrator of PDXScholar. Please contact us if we can make this document more accessible: pdxscholar@pdx.edu. 


\title{
A STUDY OF VAASHINGTON SECONDARY PRINCIPALS' PERCEPTIONS OF EFFECTIVE DROPOUT PREVENTION POLICIES AND PROGRAMS
}

\author{
by \\ SUSAN LINDSLEY GREENWOOD
}

A dissertation subinitted in partial fulfillment of the requirement for the degree of

\author{
DOCTOR OF EDUCATION \\ in \\ EDUCATIONAL LEADERSHIP: \\ ADMINISTRATION AND SUPERVISION
}

\author{
Portland State University \\ (C) 1990
}


TO THE OFFICE OF GRADUATE STUDIES:

The members of the Committee approve the dissertation of Susan Lindsley Greenwood presented May 4, 1990.

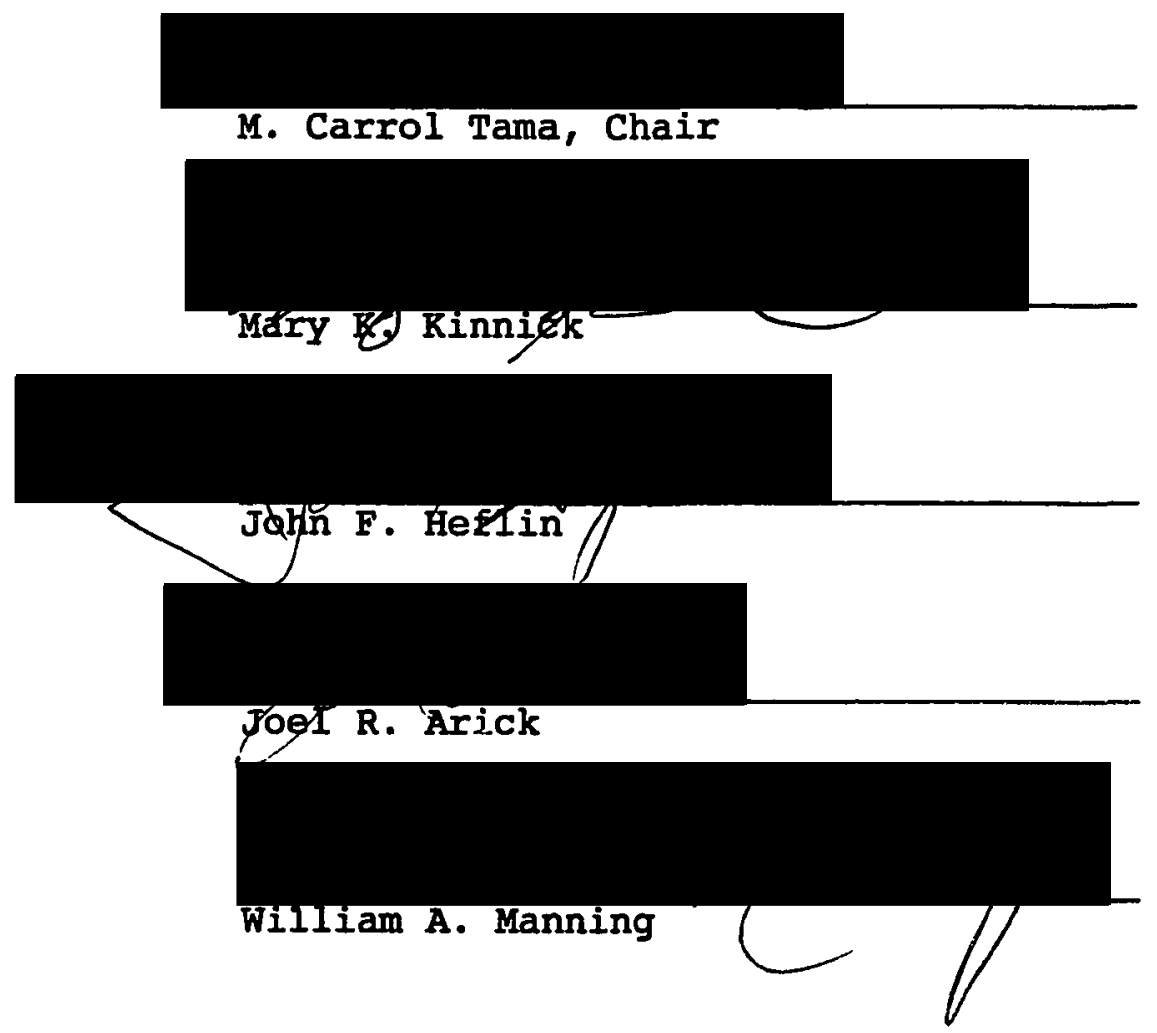

APPROVED:

Robert B'. Everhart, Dean, School of Education

C. William Savery, Interim $\$$ ice Provost for Graduate Studies and Research 


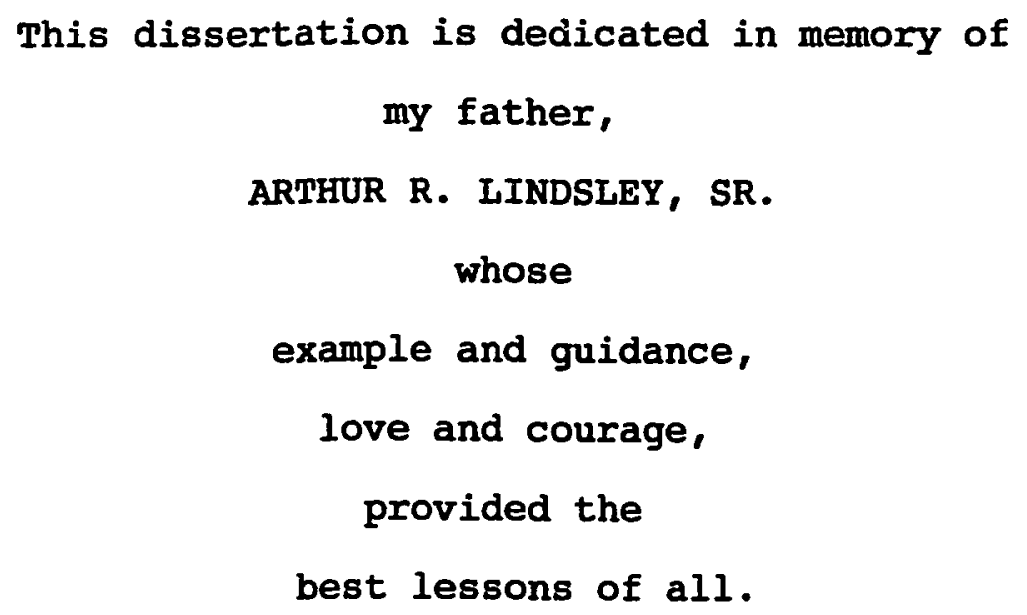




\section{ACKNOWLEDGEMENTS}

Sincere appreciation is expressed to Dr. M. Carrol Tama, chair of my dissertation and advisory committees, who encouraged me to continue under challenging circumstances and reminded me that "nothing was insurmountable." Her assistance and support in the final stages of this project enabled completion and closure for which I will always be grateful.

My respect, admiration, and appreciation is extended to Dr. John Heflin and Dr. Mary Kinnick for their expertise, leadership, and encouragement who guided me on both my advisory and dissertation committees.

My admiration and gratitude to Dr. Joel Arick is extended not only for his expertise in statistical analysis and in the use of SYSTAT, but for his remarkable patience, caring manner and invaluable assistance.

My appreciation is extended to Dr. William Manning for his time and contributions given to this paper and for being willing to serve on my committee.

Dr. Mary Rose and Dr. Phyllis Lee are greatly appreciated for their inspiration and intermittent assistance and guidance throughout my entire program. 
Ms. Danielle Heermann, Ms. Cheryl Montgomery, and Ms. Tammy Walker are thanked for the enumerable hours spent helping me input the data into the computer, coding the surveys, and preparing the mailings.

Ongoing support and encouragement from colleagues during this project has kept me afloat; gratitude is extended to Mr. Chris Thompson, Dr. Ben Acker, Mr. Dick Bernards, Mr. Larry Clow, Mrs. Phyllis Hyatt, Mr. Bob Hyatt, and Mrs. Mary Dynes for their thoughtfulness.

Appreciation is expressed to my dearest friend, Ms. Carole Jones, for her everlasting support, challenging thoughts, and provocative questions.

Love and appreciation is continually extended to my brothers and their wives, Hal and Rozella Lindsley, and Ray and Mary Lindsley for their belief in my completion of this project.

Finally, I especially thank my three sons, Kevin, Kyle, and Corey for their love, patience, and endurance during this time.

Susan Lindsley Greenwood 
TABLE OF CONTENTS

PAGE

ACKNOWLEDGEMENTS . . . . . . . . . . . . . . . iv

LIST OF TABLES . . . . . . . . . . . . . . . . $x$

LIST OF FIGURES . . . . . . . . . . . . . . . . . xi

\section{CHAPTER}

I

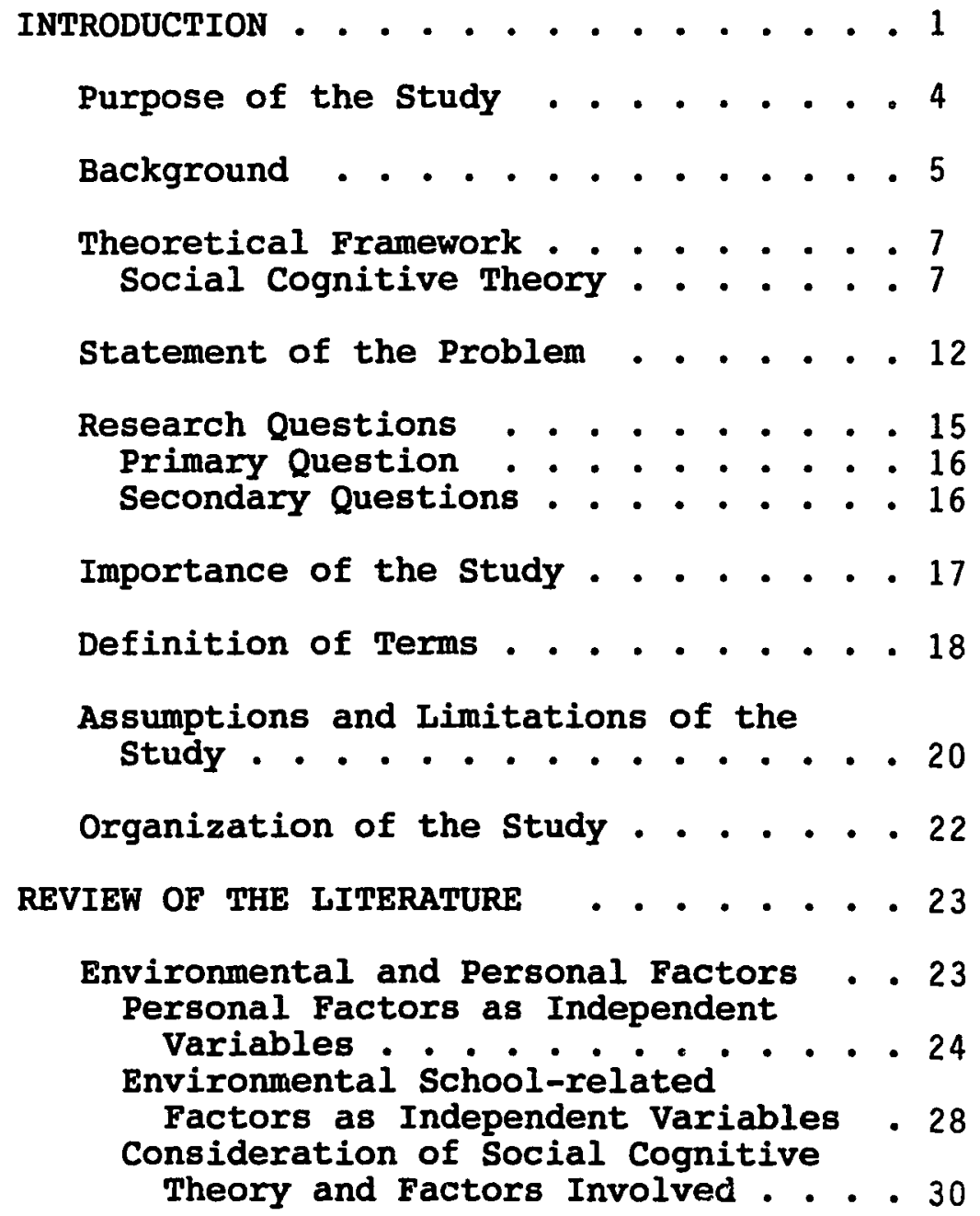


Remediation and Program Descriptions . . . . . . . . 33 Specific Programs and Results Where Reported ......... 35

Summary . . . . . . . . . . . 35

III METHODOLOGY AND PROCEDURE . . . . . . 43

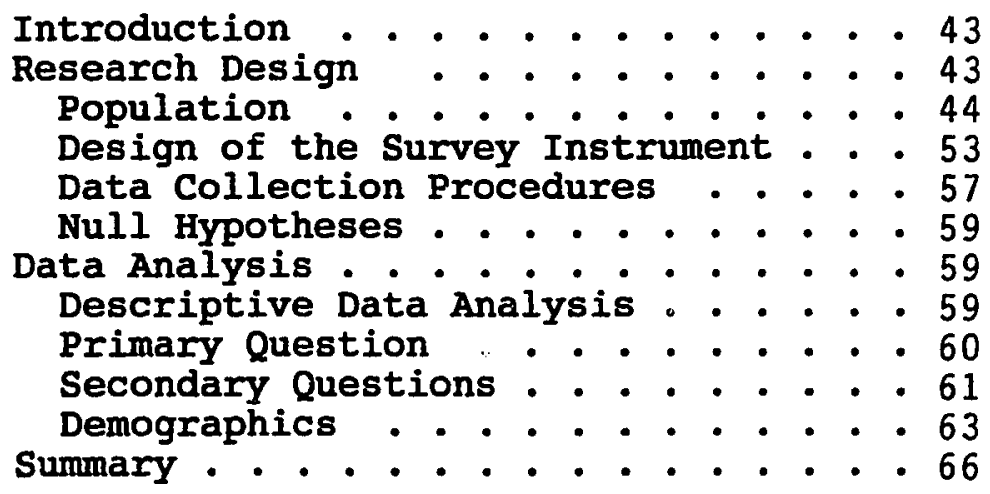

IV PRESENTATION AND ANALYSIS OF DATA • • • 67

Introduction . . . . . . . . 67

Question One (a). What preventative measures, intervention programs or student services designed to enhance environmental and personal factors are perceived to have reduced dropout rates in the sample? . . . . . . . . . . . 68 Question One (b). Does the availability of these services and programs account for a significant difference in the actual dropout

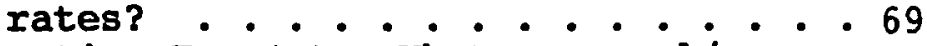

Question Two (a). What personal/ psychological factors characterize potential dropouts? . . . . . . 71

Question Two (b). Do these identifying characteristics account for a significant variance in the actual dropout rates? .. . . . . 75 Question Three (a). What environmental factors influence dropout rates in the schools? . . 76 
Question Three (b). Do these factors account for a significant variance in the actual dropout rates? .. . . . . . . . . . 80

Question Four. What intervention programs or student services are available in the sample? . . . . . 81

Question Five. What demographic factors in the sample schools significantly affect dropout rates? . . . . . . . . . . 83

Qualitative Data .. . . . . . . 89

Summary of Qualitative Data . . . . . 92

Summary . . . . . . . . . . . 104

V SUMMARY, CONCLUSIONS, RECOMMENDATIONS • • 106

Summary • • • • . • . . . . . 106

Primary Question . . . . . . . 107

Secondary Questions . . . . . . . 108

Conclusions . . . . . . . . . . . 109

What preventative measures, intervention programs or student services designed to enhance environmental and personal factors are perceived to have reduced dropout rates in the sample? . . . . . . . . . . 109

Does the availability of these services and programs account for a significant difference in the actual dropout rates? . . . . . 116 What personal/psychological factors characterize potential dropouts? - 117

Do these identifying characteristics account for a significant variance in the actual dropout rates? .......... . . . 118

What environmental factors influence dropout rates in the schools? . . . . . . . . . . . 119

Do these factors account for a significant variance in the actual dropout rates? . . . . . 120 What intervention programs or student services are available in the sample? . . . . . . . 121 
CHAPTER

PAGE

What demographic factors in the sample schools significantly affect dropout rates? . . . . . 122

Recommendations . . . . . . . . . 125

Recommendations for Further Research. . 127

REFERENCES . . . . . . . . . . . . . . 130

APPENDIX A: Cover letter mailed with five-part 130 survey instrument . . . . . . . . . . .

APPENDIX B: Five-part survey instrument . . . . . . 138

APPENDIX C: Southwest Washington survey taken

in 1988 . . . . . . . . . . . . . . . 147 


\section{LIST OF TABLES}

TABLE

PAGE

I

II

III

IV

V

VI

VII

VIIII

$X I$

$\mathbf{X}$

$X I$
Examples of Counseling/Advising

Related Programs . . . . . . . 36

Examples of Alternative

Curriculum/Classes Programs . . . . 37

Examples of Work-Related Programs . . . 38

Examples of Putorial Programs . . . . 39

Examples of Attitudinal/

Self-Awareness Programs . . . . . 40

Example of Parental Involvement

Program . . . . . . . . . . . 41

Examples of Attendance/Achievement

Incentive Programs . . . . . . . 41

Geographic Setting of Respondent

Schools ......... . . . 45

Enrollment Size of Respondent Schools . . $\$ 6$

Estimated Average Number of Students

Per Classroom . . . . . . . . . 47

Estimated Per Pupil Expenditure for

Responding Districts . . . . . . . 48

Estimated Average Household Income

of Respondent Building's Students . . 49 
XIII

XIV

XV

XVI

XVII

XVIII

$\mathbf{X X}$

XXI

XXII
Economic Stability of Respondent

Schools' Community . . . . . . . 50

Gender of Respondent Principals . . . . 51

Age of Respondent Principals . . . . 52

Percentage of Students Using the Free

School Lunch Program . . . . . 53

Racial Diversity of Respondent Schools. . 54

Respondent's Opinions of Most

Effective Policies, Services, and

Programs in Reducing Dropout Rates . . 69

Multiple Regression on Available

Programs with Total, Girls', and

Boys' Dropout Rates . . . . . . 71

Response Means and Standard

Deviations Regarding Personal

Factors Identifying Potential

Dropouts . . . . . . . . . . 72

Comparison of Research on Dropouts'

Characteristics with Respondents'

Opinions . . . . . . . . . . . . 74

Identified Characteristics of

Potential Dropouts Accounting for

the Variance in Actual Dropout

Rates . . . . . . . . . 76 
XXIII Responses Regarding Environmental

Factors Identifying Fotential

Dropouts . . . . . . . . . . 77

XXIV Environmental Factors Accounting for

the Variance in Actual Dropout

Rates .............. . 81

XXV

District and Building Policies,

Services, and Programs offered in

Respondents' Schools . . . . . . 82

XXVI Dropout Rates for Respondent Schools . . 85

XXVII Analyses of Variance on Demographic

Variables with Dropout Rates . . . 86

XXVIII Summary of Qualitative Data as it

Pertains to the Research Questions . 90 


\section{LIST OF FIGURES}

\section{FIGURE}

PAGE

1. Bandura's (1986) Schematic Hodel of the

Relations Between the Three Classes of

Determinants in Triadic Reciprocal

Causation . . . . . . . . . . . 2

2. Bandura's (1986) Schematic Model of the

Relations Between the Three Classes of

Deteiminants in Triadic Reciprocal

Causation and Showing the Relationship

Between the Independent Variables and

Dependent Variable . . . . . . . . 60

3. Comparison of Dropout Rates by Economic

Stability of Community . . . . . . . 88 
AN ABSTRACT OF THE DISSERTATION OF Susan Lindsley Greenwood for the Doctor of Education in Educational Leadership: Administration and Supervision presented May 4, 1990.

Title: A Study of Washington Secondary Principals' Perceptions of Effective Dropout Prevention Policies and Programs

APPROVED BY THE MEMBERS OF THE DISSERTATION COMMITTEE:

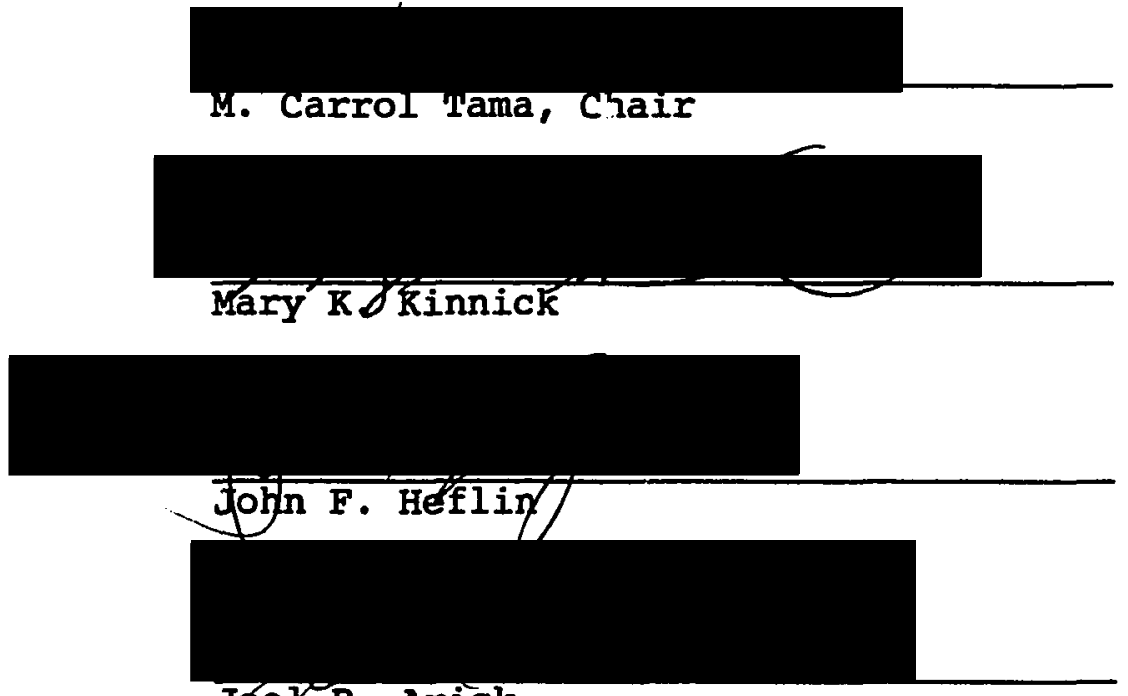

Jól R. Arick

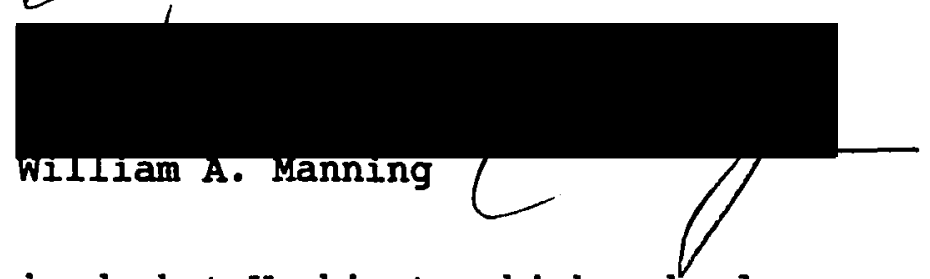

This study examined what Washington high school principals perceive to be the most effective dropout 
prevention policies and programs. The population included all public high schools in the State of Washington.

Five questions were posed:

1. (a) What preventative measures, intervention programs or student services designed to enhance environmental and personal factors are perceived to have reduced dropout rates?

(b) Does the availability of those services and programs account for a significant difference in the actual dropout rates?

2. (a) What personal / psychological factors characterize potential dropouts?

(b) Do these identifying characteristics account for a significant variance in the actual dropout rates?

3. (a) What environmental factors influence dropout rates in the schools?

(b) Do these factors account for a significant variance in the actual dropout rates?

4. What intervention programs or student services are available in the sample?

5. What demographic factors in the sample schools significantly affect dropout rates?

The study incorporated both quantitative and qualitative methodology. Ninety six questionnaires were 
returned for a response rate of 64 percent. The survey gathered information about each school's demographics, opinions about potential dropouts' identifying characteristics, opinions about the school environment, availability of services and programs in each building and district, and which programs iney felt to be the most effective, ranking the top ten from a list of twenty possible programs, policias, or services. Six schools were visited and their principals were interviewed to get additional information about their programs and effectiveness.

Data was statistically analyzed using ANOVA, multiple regression, and paired comparisons.

The policies, services, and programs felt tc be most effective were: In-house progressive discipline, vocational programs, a written building attendance policy, out-of-building alternative programs, cooperative work programs, freshman bonding programs, small group advisories, in-building alternative programs, a written district attendance policy, a required life skills class, honors courses, and alcohol/drug-related programs. Available programs accounting for a variance in actual dropout rates were: Monetary incentives, child care facilities, English taught as a second language, honors courses, and parent effectiveness programs. 
Identified personal characteristics accountin' for a variance in actual dropout rates were: Working full-time, low self-esteem, parents' background, low grades, teen pregnancy, and being of a racial minority.

Environmental factors accounting for a variance in actual dropout rates were: High parent and community involvement with the school, self-esteem classes and small-group advisories, and the Excellence reform.

Demographic factors accounting for a variance in actual dropout rates were: economic stability, gender of principal, and use of free school lunch.

The research suggests that those programs and practices accounting for a variance in actcal dropout rates should be examined for their interaction of involved factors. If the discussed personal and envircnmental factors are present, those effective interactive practices should be implemented in order to reduce dropout rates. 
CHAPTER I

\section{INTRODUCTION}

Currently, one-third of the 40 million school-aged children in the United State are at risk of either failing school, dropping out, or falling victim to crime, drugs, teen-aged pregnancy or chronic unemployment (Perpich, 1989). Pallas (1987) reports that approximately 258 of adolescents nationwide do not graduate with a degree or diploma.

While 22.38 of those from the poorest social classes dropped out of the 1980 sophomore cohort followed in "High School and Beyond", Kolstad and Owings (1986) report that 8.98 of the wealthiest social classes also dropped out. According to Margaret LeCompte (cited in Raeburn, 1987), many school dropouts are ranked in the top quarter of their class, and some are less than 14 years old. The failure to recognize the existence of these new dropouts may explain why programs designed to keep students in school are not. working. These new dropouts include the very young, the middle class, the gifted, the bored, the young parent, and the ideologically committed.

Although a variety of descriptors have been offered that characterize the dropout, little has been discussed 
about how the environment or programs affect the at risk student. Therefore, the research questions are examined in light of Bandura's Social Cognitive Theory (1986). Theories can provide predictive power as well as also explain changes in outcomes. Social cognitive theory embraces an interactional model in which environmental events (E), personal factors (P), and behavior (B) all operate as interacting determinants of each other. Bandura formed a schematic model that illustrates this theory of triadic reciprocal determinism (Figure 1).

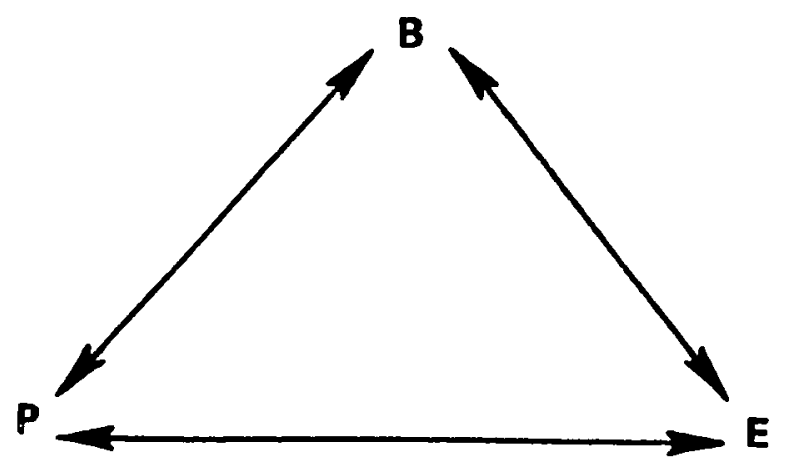

Figure 1. Bandura's (1986) schematic model of the relations between the three classes of determinants in triadic reciprocal causation.

In this triadic reciprocal determinism, the term reciprocal refers to the mutual action between causal factors. The term determinism is used here to signify the production of effects by certain factors. Because of the multiplicity of interacting influences, the same factor can be a part of different blends of conditions that have different effects. 
Besides separating factors that school cannot control from elements that school can affect, it is relatively unknown if any or which various intervention methods or assisting services have improved a specifj.c school's graduation rates. Numerous ideas and programs have been recommended (Zobrist, 1985). Reviews of dropout programs suggest that successful programs often mix academic and vocational studies, provide more individualized instruction, and use a teaching staff more sensitive and responsive to the needs of the students.

Little attention has been given to the influences of schools themselves--their organization and authority structure, leadership, teachers, curriculum--on students' decisions to drop out. Yet many dropouts attend schools with very poor facilities and inadequate teaching staffs, conditions that could affect their performance in school and ultimately their decision to leave school (Fine, 1986). Other environmental factors such as school size, location, and socioeconomic composition of the school have also surfaced in the literature on dropouts.

Many schools, districts and states have instituted policies and programs to address the dropout issue. National recommendations have been made to stem this ever-increasing problem. While several recommendations and reviews have been made regionally and nationally, few 
empirical conclusions have been drawn as to what has been most effective in preventing early dropout. Because some regional successes can be applied to other similar regions and because several authors suggested that smaller schools would result in lower dropout rates, Greenwood (1988) conducted a four-county survey in Southwestern Washington to see if small schools had lower dropout rates than large schools. The study found that smaller school size did not confirm earlier research conclusions based on a national sample. It was found that schools with over 1,000 students had a five percent higher graduation rate; and the girls in the large schools had a significantly higher graduation rate. If smaller school size was not associated with lower dropout rates, it was important to find out what other school factors were believed to result in lower dropout rates. Research findings for Washington state could then be suggested for other regions of the United states.

PURPOSE OF THE STUDY

Results of Greenwood's study led to the main focus for this research: What available preventative measures, intervention programs or student services designed to eninance environmental and personal factors are perceived to have reduced early dropout? This study also examined personal / psychological factors characterizing potential 
dropouts, environmental factors influencing dropout rates in the schools, availability of intervention programs or student services in the sample, and demographic factors which significantly affected dropout rates.

If policies and programs perceived to improve interactional dynamics are identified and practiced within the school environment, one should be able to predict that a school's dropout rate will decrease. Moreover, if practices and programs are effective in helping each student to take responsibility for completing his or her graduation requirements, Bandura's theory is supported by helping to explain effective mechanisms. With secondary school dropout rates ranging from 4 to 65 percent in the southwest region of Washington (Greenwood, 1988), it will be beneficial to find which environmental factors, including programs and services, are perceived to have been effective in increasing a student's staying power to graduation and recommend those findings for practice where possible.

\section{BACKGROUND}

In the 1960 s responsibility for failure in school seemed to be assigned to the student and his or her tragic social situation. If these students did not learn in school it was their fault... now... we know better who these youth are and the extent of their ever-worsening problems. It is not just that some students may be black or Spanish-speaking or illiterate or disruptive or pregnant or in danger 
of dropping out or have already left school... Inside these schools, absenteeism and failure rates are already astronomically high. ...students are being disconnected from the functions of society, not just from economic productivity, but from the functions of citizens in a democracy. The essential knowledge and skills needed to participate adequately in contemporary life have expanded far beyond the grasp of an unusually large number of young Americans (Barr, 1988 , p. 1).

The trend in early dropout has remained steady and even increased. Minority populations, who have always had higher dropout rates than the white population are increasing in public schools (Rumberger, 1987). Recent legislation and education reforms to raise academic course requirements for high school graduation may require major efforts to prevent more students in this high-risk population from dropping out.

Additional factors associated with dropping out can be included into several major categories including: demographics, family-related, peer, school-related, economic, and individual. Ferhaps the most important is socioeconomic status (Kolstad \& Owings, 1986). Particular family-related factors associated with dropping out include low educational and occupational attainment levels of parents, low family income, speaking a language other than English in the home, single-parent families, and the absence of learning materials and opportunities in the home (Ekstrom et al., 1986; Rumberger, 1983).

Or as Conrath (1986) states: 
These students see little relationship in their lives between effort and achievement; between cause and effect in behavior. As such they are "externalizers," people who see life and events as outside their inner control, and therefore, see little need to take responsibility for what happens in their life (p. Cl).

It is [emphasis added] important to discriminate between causative factors that the school cannot change--low socioeconomic status, single-parent homes, large families, minority status--and other factors which the school could change--low self-esteem, an external locus of control, or a lack of trust in the school disciplinary system (Wehlage \& Rutter, 1986).

\section{THEORETICAL FRAMEWORK}

\section{Social Cognitive Theory}

In the social cognitive models of interactive agency, persons are neither autonomous agents nor mechanical conveyors of environmental forces. People are neither driven solely by inner forces nor automatically shaped and controlled by external stimuli. Social cognitive theory embraces an interactional model in which environmental events, personal factors, and behavior all operate as interacting determinants of each other (Bandura, 1986). Numerous findings indicate that the major determinants of behavior arise from these transactional dynamics. 
The remarkable capacity to use symbols of a familiar environment provides people with a powerful means of altering and adapting (Bandura, 1986). From observing the actions and consequences happening within their environment, they similarly give meaning, form, and continuance to their life experiences. By drawing on their knowledge and adaption powers, people can generate innovative courses of action. Rat. than solving problems totally by taking an immediate action and suffering the consequences, people usually consider a variety of actions symbolically and do them or decide against them based on the estimated outcomes. By imagining foreseeable outcomes symbolically, for instance, being around people who prepare and study for school, who achieve academic honors, and who succeed after graduation, people can imagine their future consequences into current motivators and regulators of foresightful behavior (Bandura, 1986).

In addition, much learning can come from observing other people's behavior and the consequences thereof. The abbreviation of the acquisition process through observation is vital for both development and survival. Research on how outcomes regulate behavior has been predominantly concerned with immediate external effects. But external consequences, as influential as they often are, are not the only kind of outcomes that determine human behavior. 
People partly guide their actions by observed consequences (Bandura, 1986).

Further, behavior is motivated and regulated by internal standards and self-evaluative reactions to one's behavior. While these self-regulatory functions do have some external origins and functions, this does not refute the fact that the exercise of self-influence partly determines the course of one's behavior. Among the types of thought tiat affect action, none is more central or pervasive than people's judgments of their capabilities to deal effectively with different situations.

The research questions are examined in light of Bandura's social cognitive theory (1986). Because of the triadic reciprocality in this theory, environmental influences (independent variables), cognitive and other personal factors (indeperdent variables), and behavior or leaving school early (dependent variable) can be examined to see if the findings indicate significant recommendations for further application of the theory. While for this study, the behavior identified as the dependent variable is dropping out of school before graduation. Thus, the arrows in the triadic model should be aimed only towards the behavioral point. However, when the researcher considers the observed outcomes of others behavior as vicarious motivators (Bandura, 1986), this enables the arrows in the 
triad to become bidirectional between all variables. There are also two specific examples in the qualitative data of this study where dropping out (behavior) affected the environmental variables.

Because of the multiplicity of interacting influences, the same factor can be a part of different blends of conditions that have different effects. Particular factors are, therefore, associated with effects probabilistically rather than inevitably (Bandura, 1986, p. 24).

Environmental factors (independent variables) such as school size, location, safety and attractiveness, socioeconomic and ethnic composition of the school, programmatic factors such as curriculum tracking and ability grouping, instructional factors such as teacher attitude and expectations, and language of instruction will be described in their effect on students' early dropout. Cognitive and personal factors (independent variables) including marriage and/or pregnancy, feelings of alienation or dislike of school, histories of disciplinary problems and/or truancy, social and economic pressures, language dominance, ethnicity, and gender will be presented in their effect on early dropout. Behavior (dependent variable) according to the theory was represented by students remaining in school. to graduation or dropping out before graduation.

Research on at risk students and dropouts supports the position that conditions driving the dropout problem 
derive from the interaction between personal /

socioculcural characteristics of students and the organizational, structural, and instructional requirements an expectations of educational institutions (zachman, 1987). Corroborating this position, Beck and Muia (cited in Pittman, 1986) state that the dropout problem originates from a lack of congruence between the cultural experiences brought to school and those necessary to perform adequately within the school environment.

This reflects a departure from the traditional position in which the root of the problem was solely associated with the background of students and their families. The significance of this change in value position is that it shifts the burden of responsibility from the student to a shared responsibility involving educational policymakers, administrators and teachers, business and industry to enable school-based reform possible (Zachman, 1987). Pittman (1986) concludes that dropout prevention programs created to focus upon the personal, social conditions in the classroom could be expected to enhance academic achievement as well as the social dimension of student life in school. 


\section{STATEMENT OF THE PROBLEM}

According to Hodgkinson (1985), nationwide school graduation rates hover around 76 percent. Studies indicate that youth with less formal training have fewer prospects for becoming productive and their chances for being a drain on the nation increase. Opportunities for getting and keeping employment decrease while demand for additional government services increases. States having the highest graduation rates tend to have small schools and small classes which may also account for better graduation rates (Hodgkinson, 1988). Although school leaders have encouraged consolidation of small schools during the major part of this century, some research indicated that smaller school size may be a significant factor in a school's ability to hold students to graduation (Barker, 1986; Jess, 1985)

After Greenwood's (1988) study to determine whether small high schools have significantly better graduation rates than large schools in southwestern Washington, it was found that girls had significantly lower dropout rates in the schools with over 1,000 students. Although not at a significant level, these larger schools also had a lower mean dropout rate than the smaller schools. Since there 
was only one significant outcome from this study, it was difficult to make further conclusions.

Kecommendations from this 1988 study included:

taking a bigger and more representative sample; surveying the economic trends within the surrounding community of the school; surveying administrator / educator opinions on what affects potential dropouts and how they are or should be helped; and finding out what programs and services are available.

Thompson (1989), member of the Washington Governor's Task Force on School Dropout Prevention, states: "...Instead of focusing on the figures, we should be looking at what we can do to keep dropouts in school... focus on what needs to be done."

The U. S. Department of Education (1983) estimates that about 14 percent of students who were sophomores in 1980 dropped out of school by 1982. This percentage represents over one-half million students. While much of the research defines effective schools in terms of student achievement, building environment, community involvement, and instructional quality and leadership, Ron Edmonds (1979) was one of the few who defined an effective school as one where all students also pass to the next level of schooling. 
Almost one out of every five Washington state students drops out of high school before graduation, according to the governor's task force ("Dropout rate," 1989). The study's figures for the 1986-87 school year show that more than 11,000 students dropped out of high school. Although the average dropout rate was 198,65 schools had rates greater than 25\%, 43 schools had rates greater than $30 \%, 16$ schools had rates greater than $40 \%$ and five schools had rates greater than 508. By 1990, it is predicted that $36 \%$ of Washington school students will be at risk because they come from poverty, minority status or single parent households (Billings, 1989). Nearly one of every three students fail to complete high school and consequently face an uncertain future in a society that increasingly has no place for them ("Dropout woes," 1989). Students failing to acquire basic skills during early years consequently falter as later grades are reached. Repeated failures make school graduation a very distant and unattainable goal.

In Washington, as in the nation, Gustafson (Washington Education Association, 1989) reports that , zenage pregnancy, suicide, child abuse and neglect, homelessness, and substance abuse have reached astounding proportions while the 25 percent dropout rate diminishes opportunity for individuals and severely hampers our 
ability to produce an adequate workforce. One-fourth of the state's children live in poverty and one-half will experience poverty during their formative years (Washington Education Association, 1989).

Jobs of the future will require higher skill levels than those of today. By 1990, thcee out of four jobs will not only require a high school education but require some education or technical training beyond high school (Youth $2000,1988)$. While graduating from high school does not ensure that a person has sufficient academic skills for successful employment and further education, failing to graduate usually ensures that person does not.

RESEARCH QUESTIONS

The study addresses the primary hypothesis of preventative measures significantly reducing dropout rates and is addressed in the first question. As part of this same question, the study will seek to find if those preventative measures actually account for a significant difference in dropout rates. The study also considers the secondary hypothesis of identifying characteristics of potential dropouts. This is posed in the second question. The next hypothesis considers environmental factors affecting dropout rates. This is addressed in the third research question. The researcher wanted to discover 
program availability for at-risk students and the information sought is asked in the fourth question. Demographic variables that affect dropout rates is asked for in the fifth question.

\section{Primary Question}

1. (a) What preventative measures, intervention programs or student services designed to enhance environmental and personal factors are perceived to have reduced dropout rates in the sample?

(b) Does the availability of these services and programs account for a significant difference in the actual dropout rates?

\section{Secondary Questions}

2. (a) What personal / psychological factors characterize potential dropouts?

(b) Do these identifying characteristics account for a significant variance in the actual dropout rates?

3. (a) What environmental factors influence dropout rates in the schools?

(b) Do these factors account for a significant variance in the actual dropout rates?

4. What intervention programs or student services are available in the sample? 
5. What demographic factors in the sample schools significantly affect dropout rates?

IMPORTANCE OF THE STUDY

While many recommendations have been made, it was ascertained that this research would find what current programs, policies, or services currently in practice are perceived to be effective in preventing dropout.

By using Bandura's (1986) triadic model of reciprocal determinism, the study also proposed to find what personal factors, environmental factors, and demographic factors significantly affect the actual dropout rates.

zobrist (1985) in his Washington Roundtable Report on School Dropouts included these major components of successful programs: a cohesive school community generating a strong sense of membership, including student and staff bonding; early identification of a problem, consistent and fair application of the standards, and a school staff that shows students they are missed when they are not in school. In addition, the Washington Governor's Task Force (Thompson, 1989) recommends: early childhood education; tutors and mentors; flexibility and alternatives; parent involvement; school, community, and interagency collaborations; at risk focus for state and 
district resources; school restructuring; and public awareness .

By studying what is perceived to be effective and then testing those factors and programs to see if a variance in the dropout rates actually occurs would provide a framework for improvement in interaction between the personal and environmental factors. Further, these findings would help school policy makers decide which programs to implement or improve.

\section{DEFINITION OF TERMS}

At risk student. For a variety of reasons, a student that is considered to be in danger of failing in school and later in his/her community; also considered to be a potential school dropout; also called high risk.

Dropout. A student who does not graduate with his or her class; also called early school leaver.

Dropout rate. Also known as attrition rate, the percent of students who did not graduate with their class. This is 100 percent minus the percentage that do graduate with their class.

Early school leaver. A student who does not graduate with his or her class; also called a dropout. 
Economically deflated. Refers to the school's community as experiencing industry recession with a decrease in housing needs.

Economically inflated. Refers to the school's community as experiencing new and/or ongoing industry with an increase in housing needs.

Economically stable. Refers to the school's community as experiencing relative consistent industry and family mobility.

FTE. Full Time Equivalency; a term used to fund a school's enrollment i.e., a vocational student is considered a .8 FTE.

Graduation rate. Also known as school holding power rate or retention rate; this is 100 percent minus the percentage that do not graduate with their class.

Large class size. A classroom with one teacher and twenty or more students i.e., a 20/1 student / teacher ratio.

Large school. For this study only, a high school building with 500 or more students. Schools are usually classified by Washington Interscholastic Athletic Association as $B, A, A A$, or AAA depending on their enrollment in the upper three grades. 
Per pupil expenditure. The amount of money a district (state) spends on each of its students. It may or may not include transportation costs.

Small class size. A classroom with one teachsr and less than twenty students i.e., a 19/1 student / teacher ratio.

Small school. For this study, a high school building with less than 500 students.

Suburban. Of or pertaining to a place which is a combination of rural and urban.

Rural. Pertaining to the country as distinguished from the city or town; tendency toward farming and/or agriculture.

Uxban. Pertaining to, characteristic of a city; or that which dwells within a city.

\section{ASSUMPTIONS AND LIMITATIONS OF THE STUDY}

The assumptions of this research project are:

1. It is assumed that educational leaders (building principals) are seeking ways to prevent students' from dropping out of school before graduation.

2. It is assumed that the State of Washington would like to reduce its public schools' current dropout rate.

3. It is assumed that a graduate's chances of participating positively in his or her community are 
improved over the dropout's opportunity to contribute positively.

The limitations of this research project are:

1. This study is limited to a randomly selected sample of all 303 public secondary schools in the State of Washington.

2. The findings of this study are limited to Washington school districts and are not necessarily generalizable to other states with different demographic characteristics.

3. The accuracy of the data collected by questionnaire is limited by (a) the perceptions, attitudes, and knowledge of the secondary administrators responding; and (b) by the clarity, reliability and validity of the questionnaire.

4. Outcomes of graduates i.e. scores on SATs or competencies gained while staying in school have not been examined.

5. The methods by which secondary schools track their dropouts have not been examined.

6. Data on early leavers who go to community colleges, or return to school (GED, night school, etc.) are not included in the study. 
ORGANIZATION OF THE STUDY

The study is organized in five chapters, a reference list, and appendices. Chapter I contains: (a) Introduction, (b) Purpose of the Study, (c) Background, (d) Theoretical Framework, (e) Statement of the Problem, (f) Research Questions, (g) Importance of the Study, (h) Definition of Terms, (i) Assumptions and Limitations of the Study, and (j) Organization of the Study.

Chapter II contains a review of related literature and research. Chapter III explains the research methodology and design for data collection and analysis. Chapter IV contains the presentation and analysis of data. Chapter V contains the summary, conclusions, and recommendations. 
CHAPTER II

REVIEW OF THE LITERATURE

The purpose of this chapter is to provide an in-depth description of professional literature relevant to the research study. By describing research methodologies, theories, and findings in the professional literature, relations can be established between elements there and the research study. It will focus on models and programs that have been implemented in a variety of regions throughout the country, many with severe dropout rates. This chapter also serves the purpose of describing information that wili assist in the interpretation of the results of the study. It is presented using Bandura's model of social cognitive theory, an interactional model in which environmental events, cognitive and personal factors, and behavior all operate as interacting determinants of each other. Behavior here will be represented by stating that students have remained in school to graduation or that they have dropped out before graduation.

\section{ENVIRONMENTAL AND PERSONAL FACTORS}

Causes and conditions driving the problem of high risk and early dropout are related to the independent 
variables of students' personal and sociocultural background as well as associated with the independent variables of school-related factors (Zachman, 1987). The current body of literature acknowledges the impact of the former but emphasizes the latter which can greatly increase the students' potential for dropping out of school (dependent variable). The literature also reflects an awareness that conditions generating the problem can be the result of an interaction between personal/sociocultural and community/school-related factors which agrees with Bandura's social cognitive theory.

\section{Personal Factors as Independent Variables}

The literature associating causes and conditions driving the problem of dropout attribute those conditions to: marriage and/or pregnancy, feelings of alienation or dislike of school and school environment, histories of disciplinary problems and/or truancy, social and economic pressures, language dominance, ethnicity, and gender (Zachman, 1987).

California state and district level data identify pregnancy as a significant factor driving the dropout problem. Analysis of data for California indicates that it is the most common reason for early school leaving under reasons classified as "personal" (California Assembly Office of Research, 1984). Stirvey data for Los Angeles 
Unified School District (1985) disclosed that staff and students agreed that pregnancy is among the major factors causing students to drop out of school. San Diego Unified School District (1985) found that seven percent of female students who left school did so for reasons of marriage, pregnancy, and hardship.

Alienation from school and dislike of school and the school environment are identified as factors creating the problem of high risk and dropping out of school. A national study of out-of-school-youth suggested that dropouts were students who felt alienated from the school environment and student body as a result of their "differentness" from other students. The dropouts were characterized as being those students who were predominantly non-White (or White, but not middle class), poor, non-English speaking, having special needs, too smart, or not smart enough (Camp, Gibbs \& Monagan, 1980). Other national data confirms that high risk students simply don't fit in and sense that they have little control over their futures (Education U.S.A., 1986).

Incidence of behavior and disciplinary problems is identified in national and district studies in California as having an impact on decisions to leave school. National survey results indicate that out-of-school youth tend to have histories which include acts of delinquency (Camp, 
Gibbs \& Monagan, 1980). In addition, truancy and poor attendance are among the causes and conditions which promote high risk of dropping out. The same study (Camp etal., 1980) suggests that in spite of compulsory attendance laws, the number of youth between the ages of twelve and seventeen who leave school is increasing; and many of those disadvantaged students who do remain in school are so rarely present that their connection to school is marginal. Wehlage and Rutter (1986) reveal that truancy and tardiness are features which distinguish dropouts from stay-ins and college-bound students. Absenteeism is such a significant factor in conditions of high risk that it is considered the most clearly identifiable predictor of dropping out (California State Department of Education, 1983).

Personal factors associated with conditions driving the at risk and dropout problem also include social and economic pressures on students. Low socio-economic status of the family is strongly correlated with dropout rates (Wehlage \& Rutter, 1986). In Appalachia, low economic status was found for 60 percent of the dropouts. Poor academic achievement was the main reason for dropping out (Cox \& Spivey, 1986). California state level data reveals that economic necessity is the second most common reason for students to drop out of school in California 
(California Assembly Office of Research, 1984). Survey data from a study of dropouts in Los Angeles Unified School District (1985) indicate that administrators, teachers, parents and students agree that family problems is among the most significant reasons for students to leave school. Administrators and teachers perceive work-related responsibilities as another primary cause while students ranked it as only a secondary factor prompting early school departure (Zachman, 1987).

Language proficiency, ethnicity, and gender are additional personal factors identified as contributing to early school departure (Education USA, 1986). However, Wehlage and Rutter (1986) found that race and ethnicity, after controlling for socioeconomic background, is not a predictor of dropping out. Austin Independent School District (1983) fourd that although ethnicity was the third strongest predictor of dropping out, no negative ethnicity factors could be found which operate independent of school-related factors. Further, the district found that all cultural characteristics related to dropping out operate through academic variables, incidence of discipline problems, and gender. 
Environmental School-related Factors as Independent Variables

The literature associating causes and conditions driving the problem of dropout attribute those conditions to: school size, location, safety and attractiveness, as well as socioeconomic and ethnic composition of the school, programmatic factors such as curriculum tracking and ability grouping, as well as age/grade placement and grade repetition, and instructional factors such as teacher attitude and expectations, and language of instruction (Zachman, 1987).

Socioeconomic composition of the school was found to account for over fifty percent of the variance in between school differences in student achievement levels (National Commission on Secondary Education for Hispanics, 1984). This study also reveals that the problem of low achievement and high risk for dropping out in these schools are further aggravated by the fact that they are overcrowded, ill-equipped, and have lower per pupil budgets than schools in adjacent areas.

This same 1984 study also cited school size as a school environmental factor associated with conditions driving the early dropout problem. Over-crowding and understaffing of schools leads to higher attrition rates. In addition, the combined factors of geographical location 
of the school and decisions regarding territorial division of the area into school districts create conditions of risk for certain schools. When cities and metropolitan areas have multiple independent school districts within their boundaries, the tax bases of inner-city districts are often insufficient to meet the needs of their low-income student bodies.

School attractiveness and safety are also school-related factors driving the dropout problem. Dangerous or unattractive physical environments lead to a higher risk of attrition, and lack of resources for making them attractive will fail to keep students in school.

Programmatic factors such as ability grouping and curricular tracking influence dropout rates. Prejudicial and inappropriate tracking correlate to early attrition (Cervantes, 1982). Academic failure and dropping out often is a result of an extremely high representation of at risk students in vocational and remedial courses (California Assembly Office of Research, 1984).

Another instructional factor driving the high risk and dropout problem is the language of instruction used in the classroom. National data indicates that language of instruction and evaluation is related to high risk because academic achievement in elementary and secondary schools hinges on English reading ability and on the results of 
standardized tests, which are given in English. Test results are often the basis for programmatic decisions such as curricular tracking, ability grouping and grade placement. The study also notes that instruction in a language in which the student is not proficient sets the stage for academic failure, and academic failure is a predictor of dropping out of school (Arias, 1984; Zachman, 1987).

Other national data indicate that there is evidence that language has an effect on teacher interactions with students and teacher expectations. The study suggests that teachers tend to act more negatively with non-English speaking students and are less likely to demonstrate the type of support which promotes achievement. It notes that findings do not clarify, however, whether negative teacher interaction precedes or follows the poor academic performance of language minority youth (Steinberg, Belinde, \& Chang, 1982).

\section{Consideration of Social Cognitive Theory and Factors} Involved

Building on ideas stemming from Bandura's theory, Gottfredson (1981) assumed that home and school experiences may be either rewarding or unrewarding; school, community, and family influence the development of stakes in conformity by the reinforcement properties of the 
environments provided; and delinquency can be prevented by altering reward structures to develop stakes in conformity and ties to parents, school, work, and nondelinquent peers. Research on high risk students and dropouts supports the value position that the causes and conditions driving the problem derive from the interaction between personal/sociocultural characteristics of students and the organizational, structural and instructional requirements of the school environment (Zachman, 1987). The literature presents a number of studies that examine the potential which interactional models, incorporating factors from both the personal/sociocultural and school-related areas, have for improving causes and conditions driving the high risk and dropout problem.

Steinberg, Belinde, and Chang (1982) suggest that the phenomena is best understood when viewed as an interaction between variables related to early academic failure, negative interactions with teachers and school personnel, and the lack of fit between the needs of language minority youth and the school. Interactional models would promote policy action by focusing on the dynamics of the process rather than on just the outcome, whether the student remains in school to graduation or drops out early. The California Assembly Office of Research (1984) examined the consequences of high dropout rates for the 
state and identified personal, economic and academic factors that influence students' decisions to leave school. The authors identified school-related factors which need to be addressed to resolve the problem, including the inadequacy of counseling services, the tendency to track minority students into remedial classes in disproportionately high numvers and into honors and college preparatory programs in disproportionately low numbers, and the narrowing of curriculum in response to budget cutbacks while increasing graduation requirements and the number and types of proficiency testing. The authors concluded that schools can become more effective in raising academic achievement of students but suggest that this would require changes in curriculum, counseling, and school organization.

Blum and Spangehl (1982) suggest that most of social science research on high risk students has resulted in piecemeal solutions and suggest that the solutions must account for the students' full range of experiences, from formal class work to extracurricular activities and home life. Wehlage and Rutter (1986) suggest that the dropout issue be redefined in a manner which takes school-related variables into account. They emphasize that this redefinition would provide a basis for school-based reform, which has not been possible when the problem is defined only in terms of the personal/sociocultural characteristics 
of students and their families. School-related factors shat should be considered in any redefinition include academic function variables (achievement and ability level, grades, and test scores) and social context of school variables such as truancy, expectations, discipline problems, tardiness and hours worked.

\section{Remediation and Program Descriptions}

In their study of Appalachia, Cox and Spivey (1986) identified seven types of remediation in the program descriptions: counseling, alternative, attitudinal, work-related programs, tutorials, parental involvement, and attendance incentives.

Counseling/Advising Related Activities. Of the reported dropout reduction/remediation activities, 25 percent could be categorized here. This included one-to-one or small group activities intended to facilitate the pupil's development of self-awareness, self-esteem, interpersonal relationships, and understanding of available options and the possible consequences of school and life decisions.

Alternative Curriculum or Classes. Another 22 percent of the activities were related to this category, including those in the regular school or at separate facilities and either as a part of the regular school day or with a different time schedule. 
Work-related Programs. Nineteen percent of the activities included prevocational, vocational, and on-the-job training.

Tutorial. Fourteen percent of the activities were considered tutorial and included remedial and supplementary assistance in individual or small-group settings.

Attitudinal and Self-awareness. Eight percent of the activities related to and included improving rapport between pupils, parents, teachers, and administrators; addressing disciplinary problems and pupil suspension, and activities such as having prominent citizens speak to pupils regarding the importance of completing school.

Parental Involvement. This included six percent of the activities and included parent conferences, home visits, parent study groups, parent counseling, and using parents as tutors or providers of support services.

Attendance Incentives. Five percent of the activities included such practices as attendance enforcement, negative reinforcement for poor attendance, and positive reinforcement for good attendance.

The great majority of the programs were sponsored by the public school systems with other community organizations and agencies, including local businesses, particularly with work-related and attendance incentive activities. Two major needs were expressed by school 
personnel in regard to the complex dropout problem, the dropout rate often being twice that of the national rate in the Central and Southern regions of Appalachia. The first neec was to find program activities appropriate for implementation with minimal resources, and the second was to implement programs that had been appropriately evaluated and found to be effective. This second part parallels the purpose for the survey done in Washington state.

\section{Specific Programs and Results Where Reported}

The dropout literature uncovered several programs aimed at preventing early school departure ("A prototype occupational," 1981; California State Department of Education, 1986; Flax, 1988; "Keeping students," 1985; Kessler, 1986; Pallas \& Verdugo, 1986; Parsley, 1989; Sisson, 1989; "At risk," 1988; "Modeling real," 1989; Stasiowski, 1989; Zuzel, 1987; Zuzel, 1988).

Using Cox and Spivey's (1986) seven categories for program descriptions, Tables I through VII outline examples of each type identified in Washington as well as in various regions throughout the nation.

\section{Summary}

While a myriad of new programs have been reported from numerous districts, counties, and states, the views of in-school administrators on what they believe to have been 
TABLB I

EXAMPLES OF COUNSEIIHG/ADVISING RBLATED PROGRAMS

\begin{tabular}{|c|c|c|}
\hline Program & Description & Bffects \\
\hline $\begin{array}{l}\text { Alleghany County, } \\
\text { North Caroline } \\
\text { counseling/ } \\
\text { listeners program }\end{array}$ & $\begin{array}{l}\text { Retired educators recruited } \\
\text { to work with identified high } \\
\text { risk 5-8 graders; working one- } \\
\text { on-one, listeners guide and } \\
\text { provide speciel frlendship. }\end{array}$ & $\begin{array}{l}\text { Plans to expand } \\
\text { with trained } \\
\text { community volunteers. }\end{array}$ \\
\hline $\begin{array}{l}\text { Ienoir County } \\
\text { Sehools New } \\
\text { Connections } \\
\text { program }\end{array}$ & $\begin{array}{l}\text { Through ongoing processes } \\
\text { providing opportunities for } \\
\text { individuals and small groups, pro- } \\
\text { vides awareness of potentials, } \\
\text { skills necessary to attain, and } \\
\text { ways to deal with stress. }\end{array}$ & None reported. \\
\hline $\begin{array}{l}\text { Vancouver, Wa. } \\
\text { Student Retention } \\
\text { and Retrieval } \\
\text { Programs }\end{array}$ & $\begin{array}{l}\text { Includes Transitions, a new } \\
\text { course focusing on developling } \\
\text { self-confidence, responsibility, } \\
\text { decision-making and goal setting. }\end{array}$ & None reported. \\
\hline $\begin{array}{l}\text { BattleGround, wa. } \\
\text { Quest, Skills for } \\
\text { Adolescence } \\
\text { program }\end{array}$ & $\begin{array}{l}\text { A curriculum program with units } \\
\text { focusing on developing a suppor- } \\
\text { tive classroom environment while } \\
\text { dealing with physical, intellec- } \\
\text { tual, social and emotional } \\
\text { development. }\end{array}$ & None reported. \\
\hline $\begin{array}{l}\text { Overton County, } \\
\text { Tennessee self- } \\
\text { awareness program }\end{array}$ & $\begin{array}{l}\text { Class established for motivation, } \\
\text { - I can" approach using computers, } \\
\text { tying in contemporary and work- } \\
\text { related skille; attended whlle } \\
\text { taking regular curriculum }\end{array}$ & Kone reported. \\
\hline
\end{tabular}


TABLB II

EXAMPLIS OF ALTERNATIVB CURRICULUM/CLASSES PROGRAMS

\begin{tabular}{|c|c|c|}
\hline Program & Description & Bffects \\
\hline $\begin{array}{l}\text { Harlan County, } \\
\text { Rentucky } \\
\text { Tutorial } \\
\text { Program }\end{array}$ & $\begin{array}{l}\text { A separate available building } \\
\text { operates three hours after } \\
\text { school, three evenings a week. }\end{array}$ & None reported. \\
\hline $\begin{array}{l}\text { Weshington City, } \\
\text { North Carolina } \\
\text { Extended Day } \\
\text { Program }\end{array}$ & $\begin{array}{l}\text { An integrated program with } \\
\text { day curriculum offered to high } \\
\text { risk or dropouts taught after } \\
\text { regular day by highly conmitted } \\
\text { and energetic staff. }\end{array}$ & $\begin{array}{l}\text { Absenteelom dropped } \\
\text { by } 18 \text { percent; dropout } \\
\text { rate was reduced by } \\
25 \text { percent. }\end{array}$ \\
\hline $\begin{array}{l}\text { Pennsylvania CSIU } \\
\text { five county STAY } \\
\text { program }\end{array}$ & $\begin{array}{l}\text { Pllot alternative program for } \\
\text { Identified junior high students. } \\
\text { Small group individualized } \\
\text { Instruction in reading and math } \\
\text { and communication skills. }\end{array}$ & $\begin{array}{l}\text { Goal is for reentry } \\
\text { into regular curric- } \\
\text { ulum; older students } \\
\text { to prepare for GBD. }\end{array}$ \\
\hline $\begin{array}{l}\text { New Haven, Ct. } \\
\text { High School in } \\
\text { the Community }\end{array}$ & $\begin{array}{l}\text { An alternative school whose three } \\
\text { basic goals include building } \\
\text { skills, increasing motivation, } \\
\text { encouraging students to become } \\
\text { responsible members of society. } \\
\text { Block classes are team-taught and } \\
\text { are inter-disciplinary. }\end{array}$ & $\begin{array}{l}\text { Gains in reading } \\
\text { okills and attitude } \\
\text { toward school. }\end{array}$ \\
\hline $\begin{array}{l}\text { Vancouver, } \\
\text { Washington } \\
\text { Student Retention } \\
\text { and Retrieval } \\
\text { Programs }\end{array}$ & $\begin{array}{l}\text { Includes a six week sumer school } \\
\text { for grades nine through twelve } \\
\text { permitting those students who } \\
\text { have fallen behind to catch up. }\end{array}$ & Mone reported. \\
\hline
\end{tabular}


TABLB III

EXAMPLES OF WORK-RELATBD PROGRAYS

\begin{tabular}{|c|c|c|}
\hline Program & Description & Bffects \\
\hline $\begin{array}{l}\text { Georgia } \\
\text { County } \\
\text { Program/ } \\
\text { School-Work } \\
\text { Partnerships }\end{array}$ & $\begin{array}{l}\text { Formelize communication } \\
\text { between industry and schools; } \\
\text { industry reinforcement of } \\
\text { school completion; only hire } \\
\text { on part-time basis. }\end{array}$ & $\begin{array}{l}\text { Increased attendance; } \\
\text { dropout decreased by } \\
8 \text { percent }\end{array}$ \\
\hline $\begin{array}{l}\text { Owsley County, } \\
\text { Rentucky career } \\
\text { preparation } \\
\text { dropout prevention/ } \\
\text { remediation } \\
\text { program }\end{array}$ & $\begin{array}{l}\text { Dropouts are recruited for } \\
\text { employability skills class } \\
\text { at night. }\end{array}$ & $\begin{array}{l}\text { Has led to } \\
\text { three evening } \\
\text { basic ed. classes; } \\
\text { no statistics } \\
\text { on reducing } \\
\text { dropout. }\end{array}$ \\
\hline $\begin{array}{l}\text { Brooks County, } \\
\text { Georgie Youth- } \\
\text { Operated Develop- } \\
\text { ment Bnterprises } \\
\text { program }\end{array}$ & $\begin{array}{l}\text { Three components including: } \\
\text { a child development center, } \\
\text { a construction-training } \\
\text { center, and a swine-breeding } \\
\text { farm. }\end{array}$ & None reported. \\
\hline $\begin{array}{l}\text { Oxford, Mass. } \\
\text { coFFEE project }\end{array}$ & $\begin{array}{l}\text { Bach occupational project } \\
\text { features job entry skills, job } \\
\text { placement skills, shadowing } \\
\text { experiences and related work- } \\
\text { study programs. }\end{array}$ & $\begin{array}{l}\text { Absenteeism, } \\
\text { vandalism, and } \\
\text { discipline problems } \\
\text { decline while } \\
\text { achievement } \\
\text { improver. }\end{array}$ \\
\hline $\begin{array}{l}\text { Vancouver, Wa. } \\
\text { Youth Employment } \\
\text { Program }\end{array}$ & $\begin{array}{l}\text { The Bducationel Service District } \\
\text { in partnership with local } \\
\text { businesses have provided pre- } \\
\text { employment training and resource } \\
\text { counseling for at riek youths. }\end{array}$ & Hone reported. \\
\hline $\begin{array}{l}\text { Vancouver, Wa. } \\
\text { YEP Career Mentor } \\
\text { Service }\end{array}$ & $\begin{array}{l}\text { In cooperation with HBIwORK and } \\
\text { PIC, the BSD provides high achool } \\
\text { youth with an adult role model } \\
\text { in the community. Hentors donate } \\
\text { time at their places of work and } \\
\text { counsel youth in terms of partic- } \\
\text { ular career goals. }\end{array}$ & Hone reported. \\
\hline
\end{tabular}


TABLE IV

BXAMPLES OF TUTORIAT, PROGRAMS

\begin{tabular}{|c|c|c|}
\hline Program & Description & Effects \\
\hline $\begin{array}{l}\text { Harlan County, } \\
\text { Rentucky } \\
\text { Tutorial } \\
\text { Program }\end{array}$ & $\begin{array}{l}\text { A separate available building } \\
\text { operates three hours after } \\
\text { school, three evenings a week. }\end{array}$ & None reported. \\
\hline $\begin{array}{l}\text { Washington City, } \\
\text { North Carolina } \\
\text { Extended Day } \\
\text { Program }\end{array}$ & $\begin{array}{l}\text { An integrated program with } \\
\text { day curriculum offered to high } \\
\text { risk or dropouts taught after } \\
\text { regular day by highly committed } \\
\text { and energetic staff. }\end{array}$ & $\begin{array}{l}\text { Absenteeism dropped } \\
\text { by } 18 \text { percent; dropout } \\
\text { rate was reduced by } \\
25 \text { percent. }\end{array}$ \\
\hline $\begin{array}{l}\text { Pennsylvania CSIU } \\
\text { five county STAY } \\
\text { program }\end{array}$ & $\begin{array}{l}\text { Pilot alternative program for } \\
\text { identified junior high students. } \\
\text { Smell group individualized } \\
\text { instruction in reading and math } \\
\text { and communication akills. }\end{array}$ & $\begin{array}{l}\text { coul is for reentry } \\
\text { into regular curric- } \\
\text { ulum; older students } \\
\text { to prepare for GBD. }\end{array}$ \\
\hline $\begin{array}{l}\text { New Haven, Ct. } \\
\text { High School in } \\
\text { the Community }\end{array}$ & $\begin{array}{l}\text { An alternative school whose three } \\
\text { basic goals include building } \\
\text { skills, increasing motivation, } \\
\text { encouraging students to become } \\
\text { responsible members of society. } \\
\text { Block classes are team-taught and } \\
\text { are inter-disciplinary. }\end{array}$ & $\begin{array}{l}\text { Gains in reading } \\
\text { skills and attitude } \\
\text { toward school. }\end{array}$ \\
\hline $\begin{array}{l}\text { Partners In } \\
\text { Learning }\end{array}$ & $\begin{array}{l}\text { Nationwide effort launched by } \\
\text { Bducation Commission of states } \\
\text { that involves mentors and peer } \\
\text { tutors at all levels of education. }\end{array}$ & Hone reported. \\
\hline
\end{tabular}


TABLE V

BXAYPLES OF ATIITUDIRAL/SELP-AWAREKRSS PROGRAMS

\begin{tabular}{|c|c|c|}
\hline Program & Description & Bffects \\
\hline $\begin{array}{l}\text { Rentucky } \\
\text { Counties/Dept. } \\
\text { of Bd./ in } \\
\text { school and } \\
\text { with community }\end{array}$ & $\begin{array}{l}\text { Developed in-house ser:ices } \\
\text { to keep students in school } \\
\text { while developing schoolf } \\
\text { community support such as } \\
\text { Big Brothers and sisters. }\end{array}$ & Mone reported. \\
\hline $\begin{array}{l}\text { Granville County, } \\
\text { North Carolina } \\
\text { Educational } \\
\text { Bnvironment } \\
\text { Bnhancement program }\end{array}$ & $\begin{array}{l}\text { Combines various theories and } \\
\text { methods Including those for } \\
\text { effective teaching, classroom } \\
\text { management, and assertive } \\
\text { discipline. }\end{array}$ & $\begin{array}{l}\text { Suspensions, an } \\
\text { indicator of future } \\
\text { dropout, were reduced } \\
\text { by } 84 \text { percent. }\end{array}$ \\
\hline $\begin{array}{l}\text { Ossining, sY, } \\
\text { Project Intercept }\end{array}$ & $\begin{array}{l}\text { Alternative to suspensions, } \\
\text { teacher in-service is critical } \\
\text { for teaching strategies, group } \\
\text { dynamics, social learning theory, } \\
\text { and family dynamics are learned. }\end{array}$ & $\begin{array}{l}\text { Dropout rate has } \\
\text { declined by } 50 \\
\text { percent. }\end{array}$ \\
\hline $\begin{array}{l}\text { Springfield, Or. } \\
\text { cadre program }\end{array}$ & $\begin{array}{l}\text { Staff members are given prevention } \\
\text { and intervention strategies to } \\
\text { be implemented within the regular } \\
\text { classroom. }\end{array}$ & Mone reported. \\
\hline
\end{tabular}


TABLE VI

BXAKPLB OF PARBNTAL INVOLVEMGNT PROGRAMS

\begin{tabular}{|c|c|c|}
\hline Program & Description & Bffects \\
\hline $\begin{array}{l}\text { McDowell County, } \\
\text { West virginia } \\
\text { parental } \\
\text { involvement } \\
\text { program }\end{array}$ & $\begin{array}{l}\text { Guidance counselor works with } \\
\text { 5th-6th graders at highest risk } \\
\text { schools; visits homes, holds } \\
\text { parent meetings, provides } \\
\text { support services. }\end{array}$ & $\begin{array}{l}\text { Has reduced } \\
\text { number of dropouts } \\
\text { by } 20 \text { percent. }\end{array}$ \\
\hline
\end{tabular}

TABLE VII

BXAMPLES OF ATTENDANCE/ACHIBVBKBNT IKCBNTIVB PROGRAMS

\begin{tabular}{|c|c|c|}
\hline Program & Description & Effects \\
\hline $\begin{array}{l}\text { Little Silver, wJ } \\
\text { Honetary reward } \\
\text { system. }\end{array}$ & $\begin{array}{l}\text { Fotential dropouts receive a check } \\
\text { for } \$ 50 \text { for coming to school, } \\
\text { arriving on time, completing } \\
\text { homework, and beheving. }\end{array}$ & Mone reported. \\
\hline $\begin{array}{l}\text { Hayward High Sch. } \\
\text { Hayward, Ca. } \\
\text { monetary reward } \\
\text { system }\end{array}$ & $\begin{array}{l}\text { At risk students can receive } \\
\text { up to } \$ 250 \text { at the end of the } \\
\text { school year if they meet academic } \\
\text { and attendance requirements. }\end{array}$ & None reported. \\
\hline $\begin{array}{l}\text { Decatur, Il. } \\
\text { Coupon reward } \\
\text { Bystem }\end{array}$ & $\begin{array}{l}\text { Disadvantaged students can get } \\
\text { up to } \$ 300 \text { in coupons redeemable } \\
\text { at local stores every three } \\
\text { months. }\end{array}$ & None reported. \\
\hline $\begin{array}{l}\text { MBSA program } \\
\text { in } 160 \text { Californie } \\
\text { schools }\end{array}$ & $\begin{array}{l}\text { Academically gifted minority } \\
\text { students can earn } \$ 10 \text { to } \$ 200 \\
\text { per academic quarter. }\end{array}$ & Mone reported. \\
\hline
\end{tabular}


the most effective practices in preventing early dropout has not been found in most cases. This study is aimed at providing additional data for the State of Washington to find what is believed to have been the most effective dropout practices in this region.

Noting the interactional factors represented in many of the programs outlined, Bandura's model of environmental events, personal factors and behavior all operating as determinants of each other, has not been examined for its underpinning in early school dropout. While Gottfredson (1981) built on Bandura's theory for the prevention of school delinquency, this study on dropouts explores what policies, programs, and services are most effective in keeping students in school until graduation through this theoretical framework. 
CHAPTER III

METHODOLOGY AND PROCEDURE

INTRODUCTION

This was a descriptive study, whose purpose was to document effective dropout prevention policies, programs, and practices as perceived by a sample of practicing secondary administrators within the State of Washington. In addition, data were collected on student characteristics, school policies, and demographic characteristics which significantly affect dropout rates. This chapter delineates the research methodology and procedures including description of the population, the design of the survey instrument, data collection, and data analysis.

\section{RESEARCH DESIGN}

Survey research was selected as the method of gathering data from a widespread geographical area and a large number of subjects. It was determined to be appropriate "because of its nature and ability to solicit extensive information from a population in various geographic locations at a relatively nominal cost" (Smith, 
1987, p. 93). Ary, Jacobs, and Razavieh (1985) state that surveys of sample populations are used for discovering the incidence and distribution of, and the interrelationships among, sociological, psychological, and educational variables, while Miskel and Sandlin (cited in Smith, 1987) confirm the pertinence of survey research to the field of educational administration. In addition, these researchers found that followup observations and interviews at buildings with programs perceived to be effective would assist with the analysis. While noninteractive methods of observations are less reactive or obtrusive and less likely to influence participants' reactions (Goetz \& LeCompte, 1984), some interactive methods will shed light on more subtle values practiced in the local community and/or school, contributing to the dropout rate.

\section{Population}

The study focused on a randomly selected sample of the 303 high schools in the state of Washington, noting that all demographic settings were represented in the sample. Although Washington tends to have a more rural representation than many other states in the nation, it was important that the urban centers such as Spokane and Seattle were included in the sample as well. The randomly selected sample of 150 schools did include both of these urban centers, so that findings could be generalized to the 
entire state. This demographic information was elicited from section one of the survey instrument.

To identify the geographic setting of each school principal responding, the respondent was asked to check either rural, suburban, or urban. A bar graph analysis showed that out of 95 school principals responding, 53 (55 percent) represented rural schools, 34 ( 35 percent) represented suburban schools, and 9 (nine percent) represented urban schools (Table VIII). Information Services at the Office of the Superintendent of Public Instruction and related sources were contacted to confirm that these percentages of rural, suburban and urban schools were representative of Washington's schools in general. However, this information was not available from these sources although it is believed to be fairly representative.

TABLE VIII

GEOGRAPHIC SETTING OF RESPONDENT SCHOOLS

$\mathrm{n}=96$

\begin{tabular}{rl}
\hline n & Percent \\
\hline Rural $=53$ & 56 \\
Suburban $=34$ & 35 \\
Urban $=9$ & 9 \\
\hline
\end{tabular}


To elicit the current building enrollment, the respondent was asked to check one of four categories ranging from 0-500 students to over 1500 students. The bar graph analysis exhibited that 45 (48 percent) of the schools had a current building enrollment of under 501 students, 20 (21 percent) held between 501 and 1,000 students, 27 (28 percent) had between 1,001 and 1,500 students, and 3 (three percent) had over 1,500 students. A descriptive analysis showed that the mean building enrollment was between 501 and 1,000 students (Table IX).

TABLE IX

ENROLTMENT SIZE OF RESPONDENT SCHOOLS

$\mathbf{n}=95$

\begin{tabular}{rcc}
\hline Enrollment & n & Percent \\
\hline Schools under 501 students $=$ & 45 & 48 \\
Between $501-1,000=$ & 20 & 21 \\
Between $1,001-1,500=$ & 27 & 28 \\
Over 1,500 students $=$ & 3 & 3 \\
\hline
\end{tabular}

Mean enrollment of all schools = between $501-1,000$ SD $=.937$

To determine average number of students per classroom, the respondent checked one of six categories ranging from 10-15 students to 35-40 students. The bar 
graph analysis revealed that the estimated average number of students per classroom were: 10 (10 percent) between 10 to 15 students, 13 (14 percent) between 15 to 20 students, 35 (36 percent) between 20 to 25 students, 37 (39 percent) between 25 to 30 students, and 1 (one percent) between 30 to 35 students. No respondents checked off the category of 35 to 40 students. A descriptive analysis showed that the mean for estimated number of students per classroom was between 20 to 25 students (Table X).

TABLE X

ESTIMATED AVERAGE NUMBER OF STUDENTS PER CLASSROOM

$\mathrm{n}=96$

\begin{tabular}{ccc}
\hline Students in Class:oom & $n$ & Percent \\
\hline $10-15$ students & 10 & 10 \\
$15-20$ & 13 & 14 \\
$20-25$ & 35 & 36 \\
$25-30$ & 37 & 39 \\
$30-35$ & 1 & 1 \\
$35-40$ & 0 & 0 \\
Mean $=20-25$ average number of students per class \\
SD $=.993$
\end{tabular}


categories ranging from under $\$ 2,500$ to over $\$ 3,500$. The bar graph analysis showed that 12 (13 percent) reported under $\$ 2,500,41$ (44 percent) between $\$ 2,500$ and $\$ 3,000,25$ (27 percent) between $\$ 3,000$ and $\$ 3,500$, and 15 (16 percent) reported over $\$ 3,500$. The mean response for this question was at the high end of the third category which would be interpreted as almost $\$ 3,000$ per pupil expenditure (Table XI) •

TABLE XI

ESTIMATED PER PUPIL EXPENDITURE FOR RESPONDING DISTRICTS

$$
\mathbf{n}=93
$$

\begin{tabular}{ccc}
\hline Expenditure & $n$ & Percent \\
\hline Under $\$ 2,500$ & 12 & 13 \\
$\$ 2,500-\$ 3,000$ & 41 & 44 \\
$\$ 3,000-\$ 3,500$ & 25 & 27 \\
Over $\$ 5,500$ & 15 & 16 \\
\hline
\end{tabular}

Mean $=$ Almost $\$ 3,000$ per pupil expenditure $\mathrm{SD}=.916$

To determine the estimated average household income for the building's students, each respondent checked one of six categories ranging from under $\$ 10,000$ to over $\$ 90,000$. The bar graph analysis reported that five (five percent) had under $\$ 10,000$ average household income, 70 (74 percent) 
had between $\$ 10,000$ to $\$ 30,000,17$ (18 percent) had between $\$ 30,000$ to $\$ 50,000$, and three ( 3 percent) had between $\$ 50,000$ to $\$ 70,000$ average household income. No responses were selected for the fifth and sixth categories of this question. Descriptive analysis showed that the mean average household income fell in the second category, between $\$ 10,000$ to $\$ 30,000$ (Table XII).

TABLE XII

ESTIMATED AVERAGE HOUSEHOLD INCOME

OF RESPONDENT BUILDING'S STUDENTS

$\mathbf{n}=95$

\begin{tabular}{rcc}
\hline Estimated Income & $n$ & Percent \\
\hline Under $\$ 10,000$ & 5 & 5 \\
$\$ 10,000-\$ 30,000$ & 70 & 74 \\
$\$ 30,000-\$ 50,000$ & 17 & 18 \\
$\$ 50,000-\$ 70,000$ & 3 & 3 \\
$\$ 70,000-\$ 90,000$ & 0 & 0 \\
Over $\$ 90,000$ & 0 & 0 \\
\hline
\end{tabular}

Mean $=\$ 10,000$ to $\$ 30,000$ average household income $\mathrm{SD}=.570$

In order to determine the economic stability of the surrounding community, Question 6 gave the respondent three categories from which to choose: inflated, stable, and deflated. The bar graph analysis informed that 23 (24 
percent) felt their community was inflated (industry is evident with an increase in new housing), that 41 (43 percent) felt it was stable (industry and family mobility is relatively constant), and that 32 ( 33 percent) felt it was deflated (industry recession with a decrease in housing needs). Descriptive statistics showed the mean response for this question to be the second category, stable (Table XIII) •

TABLE XIII

ECONOMIC STABILITY OF RESPONDENT SCHOOLS' COMMUNITY

$$
\mathbf{n}=96
$$

\begin{tabular}{lcc}
\hline Description & n & Percent \\
\hline Inflated & 23 & 24 \\
Stable & 41 & 43 \\
Deflated & 32 & 33 \\
\hline
\end{tabular}

Mean $=$ Stable surrounding community

$\mathrm{SD}=.755$

For gender of principal, the respondent was asked to mark either $M$ or $F$. The bar graph analysis revealed that 87 (91 percent) of the 96 respondents were male and that nine ( 9 percent) were female (Table XIV).

For age of principal, the respondent checked one of eight categories ranging from under 30 to over 60 , 
succeeding in 5-year intervals. The bar graph analysis showed that 1 ( 1 percent) was under 30 years in age, 4 (4 percent) between 30 to 35,17 ( 18 percent) between 35 to 40,31 ( 33 percent) between 40 to 45,20 (21 percent)

TABLE XIV

GENDER OF RESPONDENT PRINCIPALS

$\mathrm{n}=96$

\begin{tabular}{ccc}
\hline Gender of Principal & n & Percent \\
\hline Female & 9 & 9.4 \\
Male & 87 & 90.6 \\
\hline
\end{tabular}

between 45 to 50,17 (18 percent) between 50 to 55, 4 (4 percent) between 55 to 60 , and 1 ( 1 percent) over 60 years of age. Descriptive analysis showed the mean age of the school principal to be in the fourth category, between 45 and 50 years of age (Table XV).

To elicit information regarding use of free school lunch programs, the respondent was askerl to write in the percentage of the building's students using the free school lunch program. Descriptive analysis was used first. of the 92 respondents answering this question, it was reported that the minimum percentage using this program was 0 
percent--that no students requested free lunch assistance. The maximum percentage reported was 99 percent. The mean

TABLE XV

AGE OF RESPONDENT PRINCIPALS

$$
\mathrm{n}=95
$$

\begin{tabular}{lcc}
\hline Age Category & n & Percent \\
\hline Under 30 years & 1 & 1 \\
$30-35$ & 4 & 4 \\
$35-40$ & 17 & 18 \\
$40-45$ & 31 & 33 \\
$45-50$ & 20 & 21 \\
$50-55$ & 17 & 18 \\
$55-60$ & 4 & 4 \\
Over 60 & 1 & 1 \\
\hline
\end{tabular}

$$
\begin{aligned}
\text { Mean } & =45-50 \text { years of age } \\
\text { SD } & =1.319
\end{aligned}
$$

percentage of students using the free lunch program was 24 percent (Table XVI).

To determine racial diversity of the schools, each respondent filled in percentages for six categories including Black, Caucasian, Hispanic, Native American, SE Asian, and Other. From descriptive analysis used the mean percentages were computed for the following: black, 3.7 
percent; caucasian, 83.7 percent; Hispanic, 3.8 percent; native American, 4.2 percent; southeast Asian, 3.9 percent; and for other categories, .4 percent. To elicit racial

TABLE XVI

PERCENTAGE OF STUDENTS USING THE FREE SCHOOL LUNCH PROGRAM $\mathbf{n}=92$

\begin{tabular}{cccc}
\hline Minimum & Maximum & Mean & SD \\
\hline 08 & 998 & 248 & .23 \\
\hline
\end{tabular}

diversity of the school staffs, the respondent again filled in percentages for the same six categories. Descriptive analysis described the racial diversity of the school buildings' staffs: black, 2.7 percent; caucasian, 93 percent; Hispanic, 1.1 percent; native American, 1 percent; southeast Asian, .6 percent; and none were reported for other categories (Table XVII).

\section{Design of the Survey Instrument}

The survey instrument (see Appendix B) was constructed to meet several criteria. First, it needed to cover demographic items to discover the environment from which the specific high school drew its students, to find out the size of the school, to get age and gender data about the school principal, to get ethnicity data about the students 
TABLE XVII

RACIAL DIVERSITY OF RESPONDENT SCHOOLS

$$
\mathbf{n}=93
$$

\begin{tabular}{lcc}
\hline \multicolumn{1}{c}{ Ethnic Group } & \multicolumn{2}{c}{ Mean Percentages } \\
& Students & Staff \\
\hline Black & 3.7 & 2.7 \\
Caucasian & 83.7 & 93.0 \\
Hispanic & 3.8 & 1.1 \\
Native American & 4.2 & 1.0 \\
Southeast Asian & 3.9 & .6 \\
Other & .4 & .0 \\
\hline
\end{tabular}

and staff, and finally to get the number of 1988 graduates by gender. A pilot done by Greenwood (1988) on all secondary schools in a 4-county area of southwestern Washington was used as the basis for the first section (See Appendix C). In addition, SPI Report 1636A, acquired from the Office of the superintendent in Olympia, showing October, 1984, freshmen enrollments for responding schools was used to determine the dependent variable dropout rate for each school. Information collected from SPI Report $1636 \mathrm{~A}$ was not requested on the survey. In the first section, the respondent was asked to check off 12 categories for demographic information of each secondary school in the sample. Data gained here answered 
the fifth research question of the study and dealt with one point of Bandura's triadic model of social cognitive theory, environmental factors (demographic variables).

In the second section, seventeen Likert-style questions were used to get the respondents' opinions about at risk students and the perceptions of personal, community, and school qualities and situations that influence a particular student to drop out before graduation. The findings here address the second research question and Bandura's personal / psychological point of social cognitive theory as well as the third question and the environmental point of the triadic model.

In the third section, the respondents were asked thirteen Likert-style questions about attitudes and programs apparent in their building environment that would prevent a potential dropout from leaving school before graduation. This ties in the two components of Bandura's model, the personal / psychological and the behavioral point. In addition, the fourth section asked the respondents twenty-six yes/no questions regarding policies, programs, or services prevalent in their district and building. These policies and programs are those cited in the research as recommended to reduce dropout rates. The findings from these three sections answered the fourth research question. 
In the final section, the respondents were given a check list of all of the programs and poilcies previously asked about. They were then asked to check off services offered in their schools that have reduced a student's potential for dropping out, to write down additional services that had not been previously mentioned, and to rank the top ten programs in terms of their perceived effectiveness. The findings here would answer the first research question and the primary purpose for the study. Before the survey was mailed to the sample schools, a split-half reliability test was conducted on the Likert-style guestions to evaluate for internal consistency with results of .539 . The Cronbach alpha was calculated on each item in the Likert-style sections with results of .557. While none of the items were unreliable, five items reduced the reliability slightly. The survey was also field-tested by administrators and counselors in the Ridgefield and Vancouver School Districts for validity. The mean time to complete the questionnaire was fifteen minutes.

Upon 100 percent return of the field-tested surveys, minor revisions were made in wording of questions to clarify what was being asked. In addition, four percent of the respondents volunteered that teachers' caring and concern was one of the most effective qualities in 
deferring students' dropout before graduation. Since the researcher wanted to find how many of the respondents would volunteer this quality/service as a key to students' staying in school to graduation, this quality was not included in the listed part of the dropout prevention services to be ranked.

\section{Data Collection Procedures}

Data were collected by means of a five-part questionnaire which was mailed out to 150 randomly selected secondary schools in the state (see Appendix B). The surveys were mailed the second week of February, 1989. Each mailing included the five-part questionnaire, a cover letter (see Appendix A) explaining the purpose of the survey and directions for completing the questionnaire, a stamped, self-addressed envelope, and a short form for those respondents who desired a summary of the results of the study and indicating whether they would be willing to participate in a followup interview. The form including the respondent's name, address, phone number, and willingness to participate in a followup interview was coded to its specific data, and kept in a file for later observations, interviews, and summary mailings.

The Washington Education Directory, 1987-88, prepared by Barbara Krohn \& Associates, was the source for preparing the total population data base which included three hundred 
and three public secondary schools. Alternative high schools and privately funded schools were not included. October, 1984 freshmen enrollments were acquired from Information Services, SPI Report 1636A, Office of the Superintendent of Public Instruction. Raw ciropout percentages were determined for each responding school by: subtracting the number of reported 1988 graduates from the reported October, 1984 enrolled freshmen, and then dividing the difference by the freshmen enrollment ie. $100-75=25$ $/ 100=.25$ or 25 percent. This is a commonly used method of computing a raw dropout rate and was also used by Zobrist (1985) in his report done for the Washington Roundtable.

As the survey instruments were returned, each respondent's code was marked on the mailing list. After ninety-six of the 150 surveys mailed were received, freshmen enrollments were found from SPI Report 1636A so that raw dropout rates could be determined for responding schools. 
Null Hypotheses

1. There is no significant difference between any preventative measures, intervention programs, or student services and the actual dropout rates.

2. There is no significant difference between certain personal / psychological factors that characterize potential dropouts and actual dropout rates.

3. There is no significant difference between certain environmental factors and actual dropout rates.

4. There is no significant difference between certain demographic factors concerning the sample schools and their surrounding community and actual dropout rates.

\section{DATA ANALYSIS}

After sixty-four percent responses were received, the data was coded and entered into a computer, using the SYSTAT program at Portland State University.

\section{Descriptive Data Analysis}

A listing of all survey information was processed, providing descriptive statistics for each statement responded to. Bar graphs were produced for all variables to check for accuracy of data and to get preliminary information. Descriptive statistics included ranges of variables and their means, including the minimum and 
maximum dropout rates reported. Descriptive statistics, also showed which programs the responding school principals perceived to be most effective in reducing the number of dropouts. Bar graphs produced the frequency of responses to each choice and showed the percentages of each choice for all variables. Figure 2 illustrates how these varie les are labeled and interact.

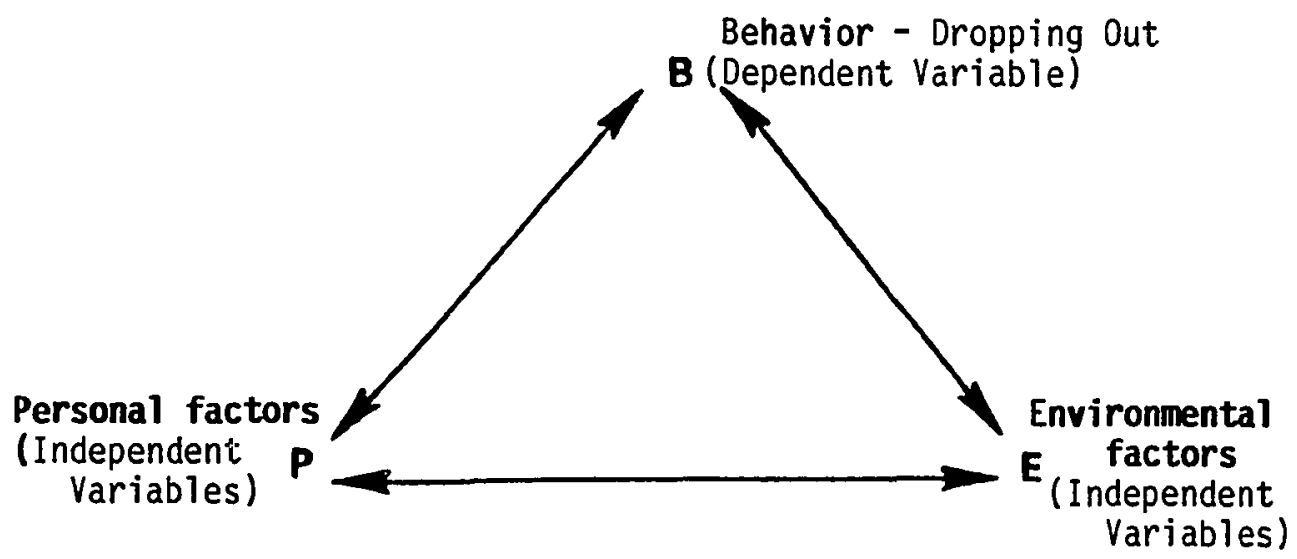

Fiqure 2. Bandura's (1986) schematic model of the relations between the three classes of determinants in triadic reciprocal causation and showing the relationship between the independent variables and dependent variable.

\section{Primary Question}

Question One (a), "What prevencative measures, intervention programs or student services designed to enhance environmental and personal factors are perceived to have reduced dropout rates?", was analyzed by reviewing the descriptive statistics, bar graphs, and overall rank order. Question 1 (b), "Do those services and programs account for 
a significant difference in the actual dropout rates?" was tested by multiple regression in order to find which program/service or combinations of programs/services accounted for the greatest amount of variance in the dropout rate. The preventative measure data came from section five of the questionnaire.

\section{Secondary Questions}

In order to answer Question Two (a), "What personal / psychological factors characterize potential dropouts?", data was provided by opinion and factual information from section two of the questionnaire. Seventeen independent variable questions were analyzed. Twelve Questions (Numbers $13-20,23,24$, and 28) related to the personal / psychological factors of poor academic history, ethnicity, gender of student, socioeconomic level, poor attendance, behavioral problems, low self esteem, lack of social integration, pregnancy, full-time jobs, and peer influence. Descriptive statistics were examined for ranges and means. Bar graphs defined frequencies and percentages of responses.

Question Two (b), "Do these identifying characteristics account for a significant variance in the actual dropout rates?", was tested by multiple regression in order to find which characteristics or combination of 
characteristics accounted for the greatest amount of variance in the dropout rate.

In order to answer Question Three (a), "What environmental factors influence dropout rates in school?", four Questions (Numbers 21, 22, 26, and 29), from section two dealt with environmental factors of gang activity, school ineffectiveness, grade retention, and school size, as well as fourteen questions from section three regarding building environment and interactions therein. One question (Number 27) from section two, stating that despite early warning signs, a potential dropout will succeed through to graduate, also alludes to transactional dynamics and could include both environmental and personal variables interacting positively for a favorable outcome or behavior. Descriptive statistics were examined for ranges and means. Bar graphs defined frequencies and percentages of responses.

Question Three (b), "Do these factors account for a significant variance in the actual dropout rates?", was tested by multiple regression in order to find which environmental factor or combination of environmental factors accounted for the greatest amount of variance in the dropout rate.

The information to answer Question Four, "What intervention programs or student services are available in 
the sample schools?", was gained from the third and fourth sections of the questionnaire and dealt with the availability of environmental variables. Descriptive statistics and bar graphs were examined regarding those responses.

Demographics

In order to answer Question Five, "What demographic factors in the sample schools significantly affect the (dependent variable) dropout rate?", an analysis of variance was done on the following demographic or independent variables: geographic setting, school size, per pupil expenditure, economic stability of surrounding community, gender of principal, age of principal, and percentage of students' using free school lunch program to the dependent variable dropout rate.

Followup interviews were requested at the end of the survey form. Six principals granting permission were contacted to make appointments for in-building visits, observations, and interviews. Selection of school visits had to meet one or more of the following criteria:

1. To get qualitative data on specific programs mentioned on the surveys including: an outcome-based instruction training program; a reportedly successful at-risk tutoring program; a child care facility; and alcohol and drug-related programs. 
2. To include at least one school having a considerably higher than mean dropout rate and to include at least one school having a considerably lower rate.

3. To include at least one school from each geographic setting: rural, suburban, and urban.

4. To include at least one school from each type of economic community: inflated, stable, and deflated.

5. To include both small and large schools.

6. To include at least one school with a female principal and at least one school with a male principal.

The six principals interviewed, schools visited, and information sought follows.

1. The first school was selected because of its suburban location, its large enrollment, its low dropout rate, and to elaborate further on programs perceived to be effective.

2. The second school was selected because of its urban location, its intermediate size, its higher than average dropout rate, and to inquire further about the school and the programs perceived to be effective.

3. The third school was selected because of its suburban location, large size, above average dropout rate, and to get further information about two programs mentioned on the survey. 
4. The fourth school was selected because of its location, extremely low dropout rate, and a reportedly outstanding at risk tutoring program.

5. The fifth school was selected becaise of its location, because of the gender of the prijıcipal, and because more information was sought on ouccome-based education schools.

6. The sixth school was selected because of its rural location, its small size, its average dropout rate, and to seek more information about innovative programs.

The format for the interview was informal. The respondent's completed questionnaire was available so that specific data about enrollment, community, and programs could be elaborated on. Specific questions asked of each principal included:

1. What is the current enrollment of your building?

2. Would you briefly describe the surrounding community?

3. How would you characterize the student body in general?

4. You indicated these policies, programs, or services as being most effective in preventing dropout in your building. Would you elaborate on these programs and why you feel that they are effective? 
SUMMARY

Survey research was selected as the appropriate means to answer the research questions posed in this study. The population surveyed included a randomly selected sample from all of the public secondary schools in Washington State. The survey instrument was designed to: (a) find what preventative measures or services are perceived to have most effectively reduced dropout rates and if they significantly affect actual dropout rates; (b) find what personal / psychological factors characterize potential dropouts and if those factors significantly affect actual dropout rates; (c) find what environmental factors influence dropout rates and if they account for a significant variance in the actual dropout rates; (d) determine intervention programs or student services that are available in each school; (e) elicit demographic information relevant to students' leaving school before graduation; (f) be clearly understood and relatively easy to complete in order to achieve a high response rate; and (g) be an accurate measuring device, through reliability and validity. The procedures for data collection and analysis were explained in relation to the type of information needed to answer the research questions. 
CHAPTER IV

PRESENTATION AND ANALYSIS OF DATA

\section{INTRODUCTION}

The data were analyzed in terms of the research questions, and will be presented on that basis. The specific research questions were:

1. (a) What preventative measures, intervention programs or student services designed to enhance environmental and personal factors are perceived to have reduced dropout rates?

(b) Does the availability of these services and programs account for a significant difference in the actual dropout rates?

2. (a) What personal / psychological factors characterize poicential dropouts?

(b) Do these identifying characteristics account for a significant variance in the actual dropout rates?

3. (a) What environmental factors influence dropout rates in the schools?

(b) Do these factors account for a significant variance in the actual dropout rates? 
4. What intervention programs or student services are available in the sample?

5. What demographic factors in the sample schools significantly affect dropout rates?

Question one (a). What preventative measures, intervention programs or student services designed to enhance environmental and personal factors are perceived to have reduced dropout rates in the sample?

To answer the primary research question, respondents were asked to rank from 1 the highest to 10 the lowest the programs they felt were the most effective in reducing dropout rates. By analyzing the means of the programs ranked, including those that had been written in, it was possible to find those perceived to be most effective. The policy/program/service with the lowest mean was the highest ranked and they are listed in succesive order from highest to twelfth ranked in Table XVIII. It is of interest to note that the twelfth program ranked most effective was not one of the items listed on the survey instrument. 
TABLE XVIII

RESPONDENTS' OPINIONS OF MOST EFFECTIVE POIICIES, SERVICES, AND PROGRAMS IN REDUCING DROPOUT RATES

$$
\mathrm{n}=87
$$

\begin{tabular}{|c|c|c|c|}
\hline Rank & Policy/Program/Service & Mean & SD \\
\hline 1 & $\begin{array}{l}\text { In-house progressive } \\
\text { discipline }\end{array}$ & 5.521 & 3.597 \\
\hline 2 & Vocational programs & 6.195 & 3.624 \\
\hline 3 & $\begin{array}{l}\text { Written building } \\
\text { attendance policy }\end{array}$ & 7.368 & 3.683 \\
\hline 4 & $\begin{array}{l}\text { Out-of-building } \\
\text { alternative programs }\end{array}$ & 7.425 & 4.025 \\
\hline 5 & Cooperative work programs & 7.793 & 3.495 \\
\hline 6 & Freshman bonding programs & 7.874 & 3.457 \\
\hline 7 & Small group advisories & 8.138 & 3.951 \\
\hline 8 & $\begin{array}{l}\text { In-building alternative } \\
\text { programs }\end{array}$ & 8.276 & 3.857 \\
\hline 9 & $\begin{array}{l}\text { Written district } \\
\text { attendance policy }\end{array}$ & 8.874 & 3.184 \\
\hline 10 & Required life skills class & 9.276 & 3.161 \\
\hline 11 & Honors courses & 9.586 & 2.443 \\
\hline 12 & $\begin{array}{l}\text { Alcohol/drug-related } \\
\text { programs }\end{array}$ & 9.611 & 2.871 \\
\hline
\end{tabular}

Question One (b). Does the availability of these services and erograms account for a significant difference in the actual dropout rates?

A multiple regression was calculated on the available programs as the independent variables with the actual 
dropout rates, with the girls' dropout rates, and with the boys' dropout rates as respective dependent variables. For this study, the correlation coefficient $R$ must be .205 at p< .05 to be considered significant. Therefore, the correlations below .205 could be due to chance. For example, while monetary incentives could have possibly accounted for a small variance (3.2 percent) in reducing the dropout rate, this variance could also be due to chance. The same result is true for child care facilities accounting for a variance in girls' dropout rates. While there is a significant correlation for English taught as a second language and honors courses accounting for a cumulative 9.2 percent of the variance in boys' dropout rates, parent effectiveness programs has a low correlation. The results are shown in Table XIX. 
TABLE XIX

MULTIPLE REGRESSION ON AVAILABLE PROGRAMS WITH TOTAL, GIRLS', AND BOYS' DROPOUT RATES

\begin{tabular}{lcc}
\hline Description & $\mathrm{K}$ & $\mathrm{R}$ Square $(\mathrm{z})$ \\
\hline $\begin{array}{l}\text { Total Dropout Rates } \\
\text { Monetary incentives }\end{array}$ & .179 & 3.2 \\
$\begin{array}{l}\text { Girls' Dropout Rates } \\
\text { Child care facilities }\end{array}$ & .174 & 3.0 \\
$\begin{array}{l}\text { Boys' Dropout Rates } \\
\text { English taught as } \\
\text { a second language } \\
\text { Honors courses }\end{array}$ & .352 & \\
$\begin{array}{l}\text { Parent effectiveness } \\
\text { programs }\end{array}$ & .265 & 5.4 \\
\hline
\end{tabular}

Question Two (a). What personal / psychological factors characterize potential dropouts?

To answer the second research question, respondents selected one of four choices, Strongly Agree, Agree, Disagree, or Strongly Disagree, by circling the response that best describes identification of potential dropouts from their experience and observations. Table $\mathrm{xx}$ shows the mean responses and standard deviations of these personal / psychological factors. 
TABLE XX

RESPONSE MEANS AND STANDARD DEVIATIONS REGARDING PERSONAL FACTORS IDENTIFYING POTENTIAL DROPOUTS

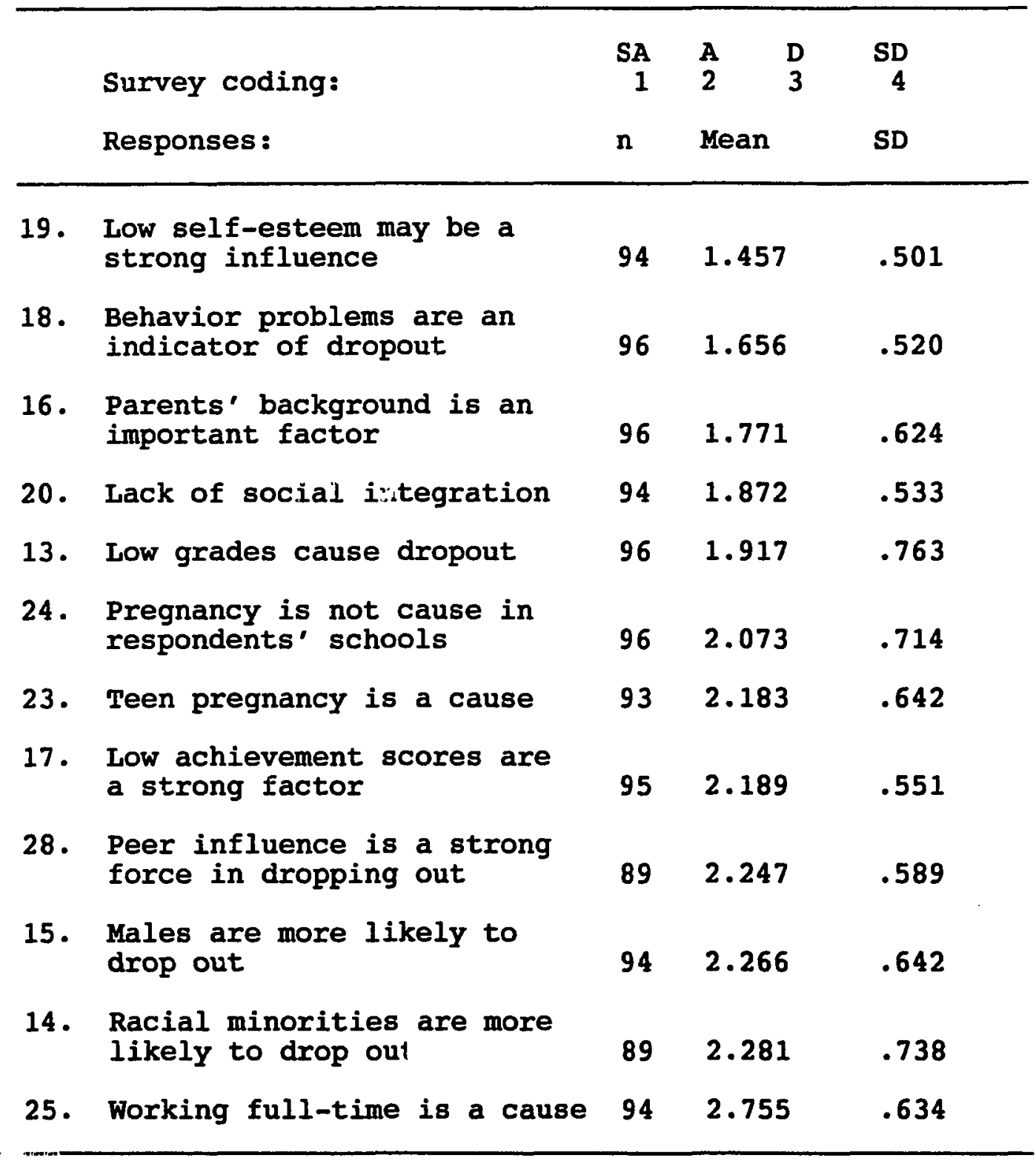

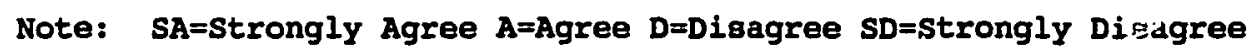


From their experience and observations, the respondents strongly agreed or agreed that low self-esteem, behavior problems, parents' backgrounds, social integration, and low grades were descriptors of defining a potential dropout. The respondents also agreed that although pregnancy would not be a cause to dropout from their school, teen pregnancy was a cause for early dropout. In addition, they agreed that low achievement scores, peer influence, being male, and being a member of a racial minority could be influences in early dropout. The respondents disagreed that working full-time was an identifier for potential dropouts. Table XXI illustrates how these responses agree or disagree with research on dropouts' characteristics. 
TABLE XXI

COMPARISON OF RESEARCH ON DROPOUTS' CHARACTERISTICS WITH RESPONDENTS' OPINIONS

Question

Agree/Disagree

13. Low grades cause dropout

Agree

14. Racial minorities are more likely to drop out

Agree

15. Males are more likely to drop out Agree

16. Parents' background is an important factor

Agree

17. Low achievement scores are a strong factor

Agree

18. Behavior problems are an indicator of dropout

Agree

19. Low self esteem may be a strong influence

Agree

20. Lack of social integration

Agree

23. Teen pregnancy is a cause

Agree

24. Pregnancy is not a cause in the resporidents' schools

Disagree

25. Working full-time is a cause

Disagree

28. Peer influence is a strong force in dropping out

Agree 
Question Two (b). Do these identifying characteristics account for a significant variance in the actual dropout rates?

A multiple regression was calculated for these identifying characteristics as independent variables with the total dropout rates, the girls' dropout rates, and with the boys' dropout rates, as respective dependent variables. The results are shown in Table XXII. There is an inverse relationship between low self-esteem and parents' background to dropout rates. For example, as these personal characteristics become more negative, there is a correlation with higher dropout rates. Other personal variables including working full-time, low grades, teen pregnancy, and being a racial minority show a positive relationship with dropout rates. As those personal characteristics became personally or within the school more prevalent, then there would be a correlation with higher dropout rates, $p<.05$. It is noted that the percentages of variance are small and that each succeeding factor is not related to the preceding factor other than it being identified as a personal characteristic. Nevertheless, working full-time was a factor for all three dropout categories. 
TABLE XXII

IDENTIFIED CHARACTERISTICS OF POTENTIAL DROPOUTS ACCOUNTING FOR THE VARIANCE IN ACTUAL DROPOUT RATES

\begin{tabular}{lll}
\hline Description & R & R Square $(8)$ \\
\hline $\begin{array}{l}\text { Total Dropout Rates } \\
\text { Working full-time }\end{array}$ & .261 & 6.8 \\
Low self-esteem & .311 & 2.9 \\
Parents' background & .353 & 2.8 \\
Girls' Dropout Rates & & \\
Low grades & .225 & 5.1 \\
Teen pregnancy & .296 & 3.7 \\
Working full-time & .383 & 2.9 \\
Being a racial minority & .342 & 2.9 \\
Boys' Dropout Rates & & \\
Working full-time & .213 & 4.5 \\
\hline
\end{tabular}

Question Three (a). What environmental factors influence dropout rates in the schools?.

In order to answer this question, five statements from section 2 (Numbers 21, 22, 26, 27, and 29) plus fourteen statements in the third section dealt with the second point of Bandura's social cognitive theory, environmental factors. While these sections deal with the building's environment, they also probe ideas regarding personal interaction within that environment. This section of the survey also examines attitudes about each building's environment rather than getting direct information about what programs were offered. The latter is directly 
approached in section four of the survey. For the third section, principals responded to each statement by circling either Strongly Agree, Agree, Unknown, Disagree, or Strongly Disagree. Table XXIII shows the mean responses and standard deviations for the statements in these sections of the survey.

TABLE XXIII

RESPONSES REGARDING ENVIRONMENTAL FACTORS IDENTIFYING POTENTIAL DROPOUTS.

\begin{tabular}{|c|c|c|c|c|c|}
\hline & Survey coding: & $\begin{array}{r}\text { SA } \\
1\end{array}$ & $\begin{array}{l}\mathrm{A} \\
2\end{array}$ & $\begin{array}{l}D \\
4\end{array}$ & $\begin{array}{r}\text { SD } \\
5\end{array}$ \\
\hline & Responses: & $\mathbf{n}$ & Mean & SD & \\
\hline 32 . & Stay-in programs exist & 96 & 1.604 & .761 & \\
\hline 34 . & $\begin{array}{l}\text { Activities involvement } \\
\text { is encouraged }\end{array}$ & 95 & 1.684 & .688 & \\
\hline 38. & $\begin{array}{l}\text { Positive teacher/student } \\
\text { relationships exist }\end{array}$ & 96 & 1.740 & .653 & \\
\hline 27. & $\begin{array}{l}\text { Despite signs of dropout, } \\
\text { students graduate }\end{array}$ & 96 & 1.854 & .355 & \\
\hline 42 . & $\begin{array}{l}\text { Wide curriculum for all } \\
\text { types of student } \\
\text { interests and abilities }\end{array}$ & 96 & 1.876 & .861 & \\
\hline 39. & $\begin{array}{l}\text { Parent, teacher, student } \\
\text { policy-making exist }\end{array}$ & 96 & 1.917 & .721 & \\
\hline 30. & $\begin{array}{l}\text { Intervention referrals } \\
\text { are made }\end{array}$ & 94 & 2.011 & .613 & \\
\hline 31. & $\begin{array}{l}\text { Temporary suspensions } \\
\text { from class occur }\end{array}$ & 94 & 2.085 & .667 & \\
\hline
\end{tabular}


TABLE XXIII

RESPONSES REGARDING ENVIRONMENTAL FACTORS IDENTIFYING POTENTIAL DROPOUTS

(continued)

29. Size of school is a factor

$92 \quad 2.413 \quad .713$

43. Separate classrooms exist for behaviorally, physically, or mentally handicapped

$84 \quad 2.452 \quad 1.145$

40. Excellence reform has increased risk

$96 \quad 2.615 \quad .999$

26. Grade retention is a factor

$\begin{array}{lll}91 & 2.659 & .687\end{array}$

41. Pride in district and building maintenance exists

$95 \quad 2.669 \quad 1.154$

37. Parent/community involvemnt exists

$95 \quad 2.674 \quad 1.132$

21. Fear of gangs is a factor

$83 \quad 2.880 \quad .670$

36. Separate facilities exist for potential dropouts

$95 \quad 2.905 \quad 1.430$

35. Self-esteem classes exist in the curriculum

$96 \quad 3.000 \quad 1.152$

33. Suspension, expulsion to alternatives do occur $93 \quad 3.161 \quad 1.191$

22. School has little effect on self esteem $\quad 94 \quad 3.362 \quad .483$

Note: $S A=S t r o n g l y$ Agree $A=A g r e e ~ U=0 n k n o w n ~ D=D i$ agree SD=Strongly Disagree 
The respondents strongly agreed and agreed that their school had discipline systems to keep students in school; a high percentage of students involved in extra-curricular activities; positive teacher/student relationships; a broad and varying curriculum; parents, teachers, and students involved in policy-making; teachers making referrals when intervention was necessary; and temporary suspensions for disruptive students. They also strongly agreed or agreed that despite these early warning signals, some students do succeed through to high school graduation.

They also agreed that the size of school could be an influence in early dropout; that their building put behaviorally, physically, or mentally handicapped students in separate classrooms; that the excellence reform had put potential dropouts at further risk; that the district was financially able to maintain buildings and classrooms and took pride in these; and that there was a high degree of parent and community involvement with students through various partnerships and contracts.

The responses were split in the districts providing alternative programs for potential dropouts ir a separate facility: 51 percent either strongly agreed or agreed that this was true, while 45 percent either disagreed or strongly disagreed. Four percent did not know. The responses were also split on building dropout prevention 
programs being in place through required self-esteem classes or small group advisories. Forty five percent either strongly agreed or agreed that this was true, while 49 percent disagreed or strongly disagreed. Six percent did not know. On disruptors being temporarily suspended from school or recommended to another school, 56 percent either disagreed or strongly disagreed, while 41 percent strongly agreed or agreed. Three percent did not know. All respondents either disagreed or strongly disagreed that there was little that the school could do to improve the student's self-esteem and feeling of social integration.

Question Three (b). Do these factors account for a significant variance in the actual dropout rates?

A multiple regression was conducted on the environmental factors as independent variables with the total dropout rate, with the girls' dropout rate, and with the boys' dropout rate as respective dependent variables. The results are shown in Table XXIV. High parent and community involvement accounted for a variance (12.6 percent) inversely affecting the total dropout rate, as well as the girls' ( 9.3 percent) and boys' ( 6.7 percent) dropout rate. While these are not large percents, it is noted that this involvement did account for a variance in all three categories. Self-esteem classes and small-group 
advisories also accounted for a small variance (3.1

percent) in reducing dropout rates.

TABLE XXIV

ENVIRONMENTAL FACTORS ACCOUNTING FOR THE VARIANCE IN ACTUAL DROPOUT RATES

\begin{tabular}{llc}
\hline Description & $R$ & R Square ( $)$ \\
\hline $\begin{array}{l}\text { Total Dropout Rate } \\
\text { High parent and community } \\
\text { involvement with school }\end{array}$ & .355 & 12.6 \\
$\begin{array}{l}\text { Girls' Dropout Rate } \\
\text { High parent and community } \\
\text { involvement with school }\end{array}$ & .304 & \\
$\begin{array}{l}\text { Self-esteem classes and } \\
\text { small-group advisories }\end{array}$ & .352 & 9.3 \\
$\begin{array}{l}\text { Excellence reform } \\
\text { Boys' Dropout Rate } \\
\text { High parent and community } \\
\text { involvement with school }\end{array}$ & .259 & 2.4 \\
\hline
\end{tabular}

Question Four. What intervention programs or student services are available in the sample?

The fourth section of the survey asked the respondents to circle either yes or no to eight policies, programs, or services offered either by the district or school. Then the respondent was asked to circle either yes or no to two programs offered by the district. The final eight questions of this section asked the respondent to circle either yes or no to eight programs or services 
offered by the building only. Table XxV shows the results of this section and answers the fourth research question.

TABLE XXV

DISTRICT AND BUILDING POLICIES, SERVICES, AND PROGRAMS OFFERED IN RESPONDENTS' SCHOOLS

\begin{tabular}{|c|c|c|c|c|c|c|c|}
\hline & & & Dig & ict & & Buij & \\
\hline & & & yes & no & & уев & no \\
\hline & & $\mathbf{n}$ & 8 & 8 & $\mathbf{N}$ & 8 & 8 \\
\hline 44. & Written dropout policy & 94 & 31 & 69 & 91 & 26 & 74 \\
\hline 45 & Written attend. policy & 94 & 96 & 4 & 93 & 100 & 0 \\
\hline 46. & student health center & 95 & 56 & 44 & 94 & 56 & 44 \\
\hline 47. & Child care & 95 & 22 & 78 & 94 & 11 & 89 \\
\hline 48. & TAG programs & 95 & 87 & 13 & 93 & 77 & 23 \\
\hline 49. & TESL programs & 94 & 57 & 43 & 94 & 39 & 61 \\
\hline 50. & Coop. work programs & 94 & 76 & 24 & 94 & 81 & 19 \\
\hline 51. & Parent effect. programs & 93 & 39 & 61 & 92 & 22 & 78 \\
\hline 52. & Elem./mid. sch. interv. & 89 & 57 & 43 & & & \\
\hline 53. & separate bldg. programs & 95 & 52 & 48 & & & \\
\hline 54. & Small group advisories & & & & 96 & 33 & 67 \\
\hline 55. & Life skills classes & & & & 94 & 38 & 62 \\
\hline 56. & In-bldg. alternatives & & & & 94 & 48 & 52 \\
\hline 57. & Vocational programs & & & & 95 & 96 & 4 \\
\hline 58. & Honors courses & & & & 95 & 79 & 21 \\
\hline 59. & Student monetary incenti & veg & & & 95 & 5 & 95 \\
\hline 60. & School uniforms & & & & 95 & 1 & 99 \\
\hline 61. & Freshmen bonding program & & & & 92 & 74 & 26 \\
\hline
\end{tabular}


While over 60 percent of the districts and buildings were reported to have written attendance policies, talented and gifted programs, and cooperative work programs, a majority of districts and buildings did not have a written policy regarding dropout prevention, child care facilities, nor parent effectiveness training programs. In addition, over 60 percent of the buildings reported having vocational programs, honors courses, and freshmen bonding programs, while a majority reported not having teaching English as a second language, small group advisories, life skills classes, student monetary incentives, and student uniforms. A little over 50 percent of the districts were reported to have student health centers, teaching English as a second language, elementary and middle school intervention programs, and separate building programs. Over 50 percent of the buildings also reported having student health centers, while the same amount reported not having in-building alternative programs.

Question Five. What demographic factors in the sample schools significantly affect dropout rates?

In order to answer the fifth research question, relevant data was collected regarding geographic setting, current building enrollment, average number of students per classroom, per pupil expenditure, average household income, economic stability of surrounding community, gender of 
principal, age of principal, percentage of students using the free school lunch program, and racial distribution of student body and of staff. This demographic information was elicited from section one of the survey instrument. Please see the Population section of Chapter III for the results.

The twelfth and last question of the demographics sections asked for 1988 graduation figures including a breakdown of girls graduating and of boys graduating. From this information, dropout rates were calculated for the respondent schools. After raw dropout rates were calculated, descriptive analysis showed the range of dropout rates as well as the mean dropout rate for 89 schools included in the survey. Although 96 school principals responded, raw dropout rates could be computed for only 89, since: one school did not exist in 1984, freshmen enrollments were not available, and graduation figures were not reported on the survey. Dropout percentages ranged from a minimum of -210 percent to a maximum of 56 percent. A negative dropout rate occurs when more students graduate than freshmen are enrolled four years earlier. The mean dropout rate reported for these 89 schools was 18.8 percent.

When the information was further broken down for girls and boys, the following percentages were found: 
girls' dropout rates ranged from a minimum of -142 percent to a maximum of 67 percent with a mean dropout rate of 15.8 percent; boys' dropout rates ranged from a minimum of -275 percent to a maximum of 74 percent with a mean dropout rate of 19.6 percent. The findings are shown in Table XXVI.

TABLE XXVI

DROPOUT RATES FOR RESPONDENT SCHOOLS

$\mathrm{n}=89$

\begin{tabular}{|c|c|c|c|c|c|}
\hline \multicolumn{2}{|c|}{ Total } & \multicolumn{2}{|c|}{ Girls } & \multicolumn{2}{|c|}{ Boys } \\
\hline $\operatorname{Min} 8$ & $\operatorname{Max} 8$ & Min 8 & $\operatorname{Max} 8$ & Min 8 & $\operatorname{Max}$ \& \\
\hline-210 & 56 & -142 & 67 & -275 & 74 \\
\hline$\underset{\text { SD }}{\text { Mean }}$ & $\begin{array}{l}=18.8 \\
=.299\end{array}$ & & $\begin{array}{l}15.8 \\
.305\end{array}$ & & $\begin{array}{l}19.6 \\
.385\end{array}$ \\
\hline
\end{tabular}

An analysis of variance was calculated on the demographic variables: geographic setting, enrollment size, per pupil expenditure, economic stability, gender of principal, age of principal, and use of free school lunch to dropout rates. While four of these were not significant at the .05 level, economic stabiiity, gender of principal, and use of free school lunch produced significant differences, $p<.05$ (Table XXVII). 
TABLE XXVII

\section{ANALYSES OF VARIANCE ON DEMOGRAPHIC VARIABLES WITH DROPOUT RATES}

\begin{tabular}{|c|c|c|c|}
\hline $\begin{array}{l}\text { Demographic } \\
\text { Factor }\end{array}$ & $\begin{array}{c}\text { Mean } \\
\text { Dropout Rate }\end{array}$ & $\mathbf{F}$ & $\mathbf{P}$ \\
\hline $\begin{array}{c}\text { Geographic setting } \\
\text { Rural } \\
\text { Suburban } \\
\text { Urban }\end{array}$ & NA & 1.381 & N.S. \\
\hline $\begin{array}{c}\text { Enrollment Size } \\
0-500 \\
501-1000 \\
1001-1500 \\
\text { Over } 1500\end{array}$ & NA & 1.687 & N.S. \\
\hline $\begin{array}{l}\text { Per Pupil Expenditure } \\
\text { Under } \$ 2500 \\
2500-3000 \\
3000-3500 \\
\text { Over } 3500\end{array}$ & NA & .555 & N.S. \\
\hline $\begin{array}{l}\text { Economic Stability } \\
\text { Inflated } \\
\text { Stable } \\
\text { Deflated }\end{array}$ & $\begin{array}{r}4.58 \\
21.68 \\
25.28\end{array}$ & 3.460 & $\mathrm{p}<.05$ \\
\hline 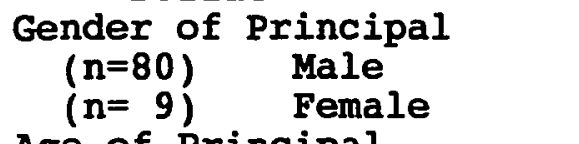 & $\begin{array}{l}22.08 \\
-9.38\end{array}$ & 9.791 & $p<.05$ \\
\hline $\begin{array}{l}\text { Age of Principal } \\
\text { Under } 30 \\
30-35 \\
35=40 \\
40-45 \\
45-50 \\
50-55 \\
55-60 \\
\text { Over } 60\end{array}$ & NA & 1.208 & N.S. \\
\hline $\begin{array}{l}\text { Use of Free School Lunch } \\
\text { Less than } 248 \\
\text { More than } 238\end{array}$ & $\begin{array}{l}13.98 \\
27.18\end{array}$ & 4.169 & $p<.05$ \\
\hline
\end{tabular}

When an analysis of variance was calculated for economic stability of the surrounding community and dropout 
rates, there was a significant difference between the three defined communities. The 23 schools reporting the surrounding community as being inflated had a significantly lower mean dropout rate ( 4.5 percent) than the 41 economically stable (21.6 percent) or the 32 economically deflated schools (25.2 percent), $F(2,86)=3.46, p<.05$ (Figure 3).

Further, when a planned comparison of the three different economic types of communities was done, it was found that there was a significant difference between the inflated communities' dropout rates and the stable community, $F(1,86)=4.609, \mathrm{p}<.05$; and a significant difference between the inflated and deflated communities, $F(1,86)=6.355, p<.05$. The difference between stable and deflated communities was not significant, $F(1,86)=.267$, p>. 05 .

When an analysis of variance was done on the independent variable, gender of principal, to the dependent variable dropout rate the ANOVA indicated a significance in gender of principal in relation to the dropout rate, $F(1,87)=9.791, p<.05$. Females principals had a significantly lower mean dropout rate ( -9.3 percent) than male principals (2' percent). 
IMTIATED

EVIDENCE OF NEW INDUSTRY WITH INCREASE IN HOUSING NEEDS

COUNT

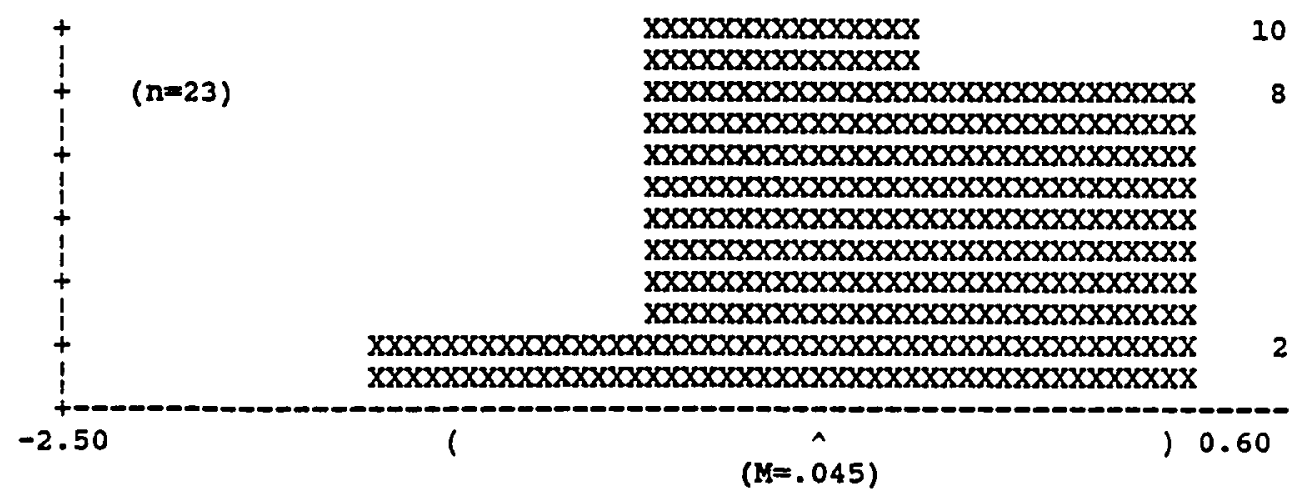

BTNBLE

INDUSTRY AND FAMILY MOBILITY IS RELATIVELY CONSTANT

COUNT

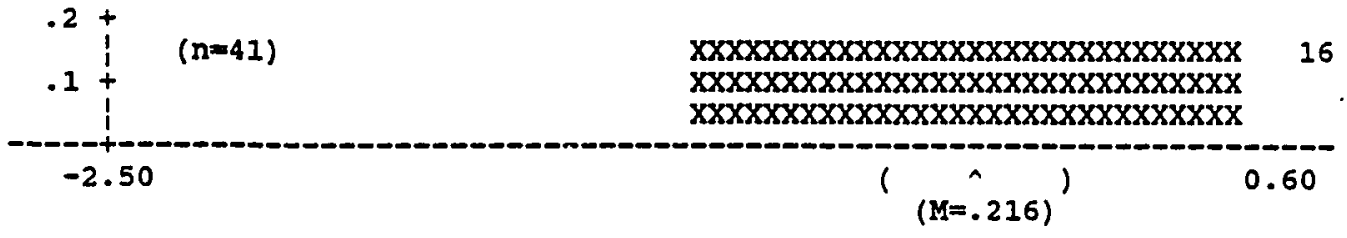

DEETATED

INDUSTRY RECESSION WITH A DECREASE IN HOUSING NEEDS

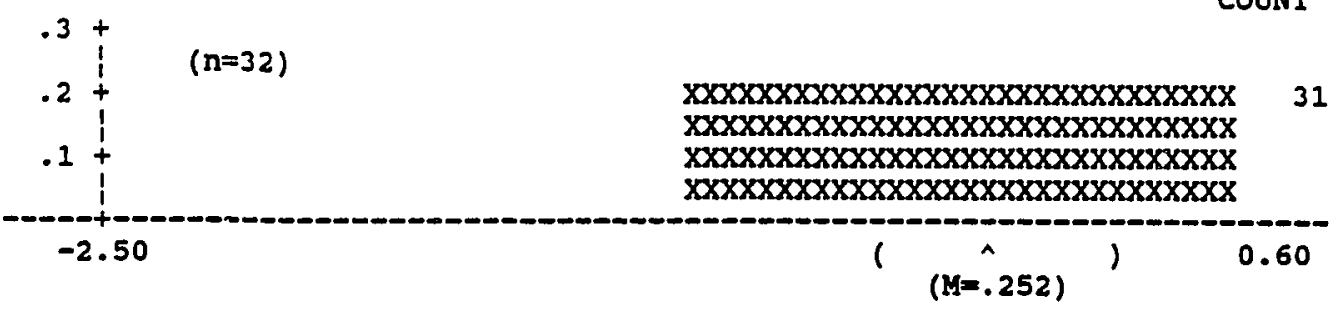

Figure 3. Comparison of dropout rates by economic stability of community. 
When an analysis of variance was done on free school lunch program rates with dropout rates, a significant relationship was found, $F(1,87)=4.169, p<.05$. Those schools with less than 24 percent of their students using the free school lunch program had a significantly lower mean dropout rate (13.9 percent) than those schools with more than 23 percent of their students using the free school lunch program (27.1 percent).

\section{Qualitative Data}

To get further details about a variety of effective programs, visits were made to six schools to inquire about those programs and their philosophies. In addition, a variety in school settings, sizes, as well as a wide range in dropouts were considered in selecting the schools from the high percentage of those granting interviews. These visits took place during the first week of June, 1989; and a summary of the variables affecting the research questions follows in Table XXVIII. 
TABLB XXVIII

SUMPARY OF QUALITATIVE DATA AS IT PBRTAINS

TO THE RBSBARCH QUESTIONS

$n=6$

\begin{tabular}{|c|c|c|c|c|}
\hline & $\begin{array}{l}\text { Perceived } \\
\text { Bffective } \\
\text { Preventions }\end{array}$ & $\begin{array}{r}\text { Personal } \\
\text { Factors }\end{array}$ & $\begin{array}{c}\text { Environmental } \\
\text { Pactors }\end{array}$ & $\begin{array}{c}\text { Demographic } \\
\text { Factors }\end{array}$ \\
\hline School 1 & $\begin{array}{l}\text {. In-house } \\
\text { progressive } \\
\text { discipline. } \\
\text {. Written bldg. } \\
\text { attendance } \\
\text { policy. } \\
\text {-In-building } \\
\text { alternative } \\
\text { programs }\end{array}$ & $\begin{array}{l}\text {.Not necessarily } \\
\text { college-bound } \\
\text {.Students with } \\
\text { developmental, } \\
\text { physical, and } \\
\text { mental diabil- } \\
\text { ities }\end{array}$ & $\begin{array}{l}\text {.Trimesters } \\
\text {.wide curriculum } \\
\text { choices } \\
\text {.Large variety of } \\
\text { school teams } \\
\text {.Pods, or schools } \\
\text { within the school } \\
\text {.Parent involvement }\end{array}$ & $\begin{array}{l}\text {.Suburban } \\
.1120 \text { FTBE } \\
\text {.Dropout } \\
\text { rate: } 78 \\
\text {.Bconomic- } \\
\text { ally } \\
\text { stable } \\
\text {. Male } \\
\text { principal }\end{array}$ \\
\hline School 2 & $\begin{array}{l}\text {. Freshmen } \\
\text { bonding } \\
\text { programs } \\
\text {. Small group } \\
\text { advisories } \\
\text {. In-building } \\
\text { alternative } \\
\text { programs } \\
\text {.vocational } \\
\text { programs }\end{array}$ & $\begin{array}{l}\text { - Large percent } \\
\text { from dysfunct,- } \\
\text { Lonal families } \\
\text {. Low socio- } \\
\text { economics } \\
\text {.Cutting classes } \\
\text { major problem } \\
\text { with students } \\
\text {.Hany students } \\
\text { bused in }\end{array}$ & $\begin{array}{l}\text { Big brother/Big } \\
\text { sister program } \\
\text {.Building mentor } \\
\text { program for at- } \\
\text { risk students } \\
\text {.Active drug- } \\
\text { intervention and } \\
\text { after care } \\
\text { program } \\
\text {.Hagnet school for } \\
\text { some vocational } \\
\text { programs }\end{array}$ & $\begin{array}{l}. \text { Urban } \\
.900 \text { FIBs } \\
\text {.Dropout } \\
\text { rate: } 418 \\
\text {.Bconomic- } \\
\text { ally } \\
\text { inflated } \\
\text {. Male } \\
\text { principal }\end{array}$ \\
\hline School 3 & $\begin{array}{l}\text {-In-building } \\
\text { alternative } \\
\text { programs } \\
\text {. In-house } \\
\text { progressive } \\
\text { discipline } \\
\text {.vocational } \\
\text { programs } \\
\text {.written bldg. } \\
\text { attendance } \\
\text { policy }\end{array}$ & $\begin{array}{l}\text {.Poor study } \\
\text { and work habits } \\
\text {.Lack of self- } \\
\text { discipline and } \\
\text { motivation } \\
\text {. Low self-esteem } \\
\text {.Lack of self- } \\
\text { confidence }\end{array}$ & $\begin{array}{l}\text {-After school } \\
\text { study program } \\
\text { aimed at } \\
\text { correcting the } \\
\text { listed personal } \\
\text { factors } \\
\text {. Parental } \\
\text { communication } \\
\text { is initiated }\end{array}$ & $\begin{array}{l}\text {. Suburban } \\
\text {. } 1300 \text { FIE8 } \\
\text {.Dropout } \\
\text { rater } 318 \\
\text {. Bconomic- } \\
\text { ally } \\
\text { deflated } \\
\text {. Male } \\
\text { principal }\end{array}$ \\
\hline
\end{tabular}


TABLB XXXVIII

SUMMARY OF QDALITATIVE DATA AS IT PERTAINS

TO THI RRSBARCH QUESTIONS

(continued)

\begin{tabular}{|c|c|c|c|c|}
\hline School 4 & $\begin{array}{l}\text { Academically } \\
\text { at risk } \\
\text { tutoring } \\
\text { program }\end{array}$ & $\begin{array}{l}\text { Improvement } \\
\text { needed in } \\
\text { attendance } \\
\text { rates } \\
\text { - Improvement } \\
\text { needed in } \\
\text { academic } \\
\text { achievement } \\
\text {-Average-to- } \\
\text { high socio- } \\
\text { economic } \\
\text { status }\end{array}$ & $\begin{array}{l}\text {-Tutors } \\
\text { recruited from } \\
\text { nearby submarine } \\
\text { base. } \\
\text { - Tutorg recruited } \\
\text { from nearby } \\
\text { engineering } \\
\text { gtation } \\
\text {-Active school/ } \\
\text { comnunity } \\
\text { partnership } \\
\text { with these tutors }\end{array}$ & $\begin{array}{l}. \text { Suburban } \\
.1050 \text { FIBs } \\
\text { in grades } \\
10-12 \\
\text {.Dropout } \\
\text { ratei -598 } \\
\text {. Bconomic- } \\
\text { ally } \\
\text { inflated } \\
\text {.Male } \\
\text { principal }\end{array}$ \\
\hline School 5 & $\begin{array}{l}\text {.Child care } \\
\text { program } \\
\text {.Outcome based } \\
\text { school } \\
\text {.Out-of-bldg. } \\
\text { alternative } \\
\text { programs } \\
\text {.Drug and } \\
\text { after-care } \\
\text { programs }\end{array}$ & $\begin{array}{l}\text {. Low acadamic } \\
\text { achievement } \\
\text {. Low socio- } \\
\text { economics } \\
\text {. Controlled } \\
\text { substance } \\
\text { abuse } \\
\text {. Low self-esteem }\end{array}$ & $\begin{array}{l}\text {-Active child } \\
\text { care/teen } \\
\text { parenting } \\
\text { program } \\
\text { "students Rights } \\
\text { and Responsi- } \\
\text { bilities" in- } \\
\text { house discipline } \\
\text { policy } \\
\text {.Outcome based } \\
\text { training for btaff }\end{array}$ & $\begin{array}{l}\text {. Urban } \\
.1300 \text { FIBs } \\
\text {.Dropout } \\
\text { rate: } 338 \\
\text {.Economic- } \\
\text { ally } \\
\text { inflated } \\
\text {.Female } \\
\text { principai }\end{array}$ \\
\hline School 6 & $\begin{array}{l}\text {.vocational } \\
\text { programs } \\
\text {.Freshmen } \\
\text { bonding } \\
\text { programs } \\
\text {. Required life } \\
\text { bkills class }\end{array}$ & $\begin{array}{l}\text {.wide range } \\
\text { of abilities } \\
\text {.One-fifth } \\
\text { thought to be } \\
\text { college-bound } \\
\text {.Attendance } \\
\text { could be } \\
\text { Improved by } \\
\text { omall percent } \\
\text {.Controlled } \\
\text { aubstance use }\end{array}$ & $\begin{array}{l}\text { Freshman Camp for } \\
\text { all freshmen during } \\
\text { first month of } \\
\text { school } \\
\text {. Washington Teen } \\
\text { Institute preven- } \\
\text { tion program }\end{array}$ & $\begin{array}{l}\text {.Rural } \\
.480 \text { FIRs } \\
\text {.Dropout } \\
\text { rate: 208 } \\
\text {.Economic- } \\
\text { ally } \\
\text { stable } \\
\text {.Male } \\
\text { principal }\end{array}$ \\
\hline
\end{tabular}


Summary of Oualitative Data

Four of the principals interviewed named at least three of the twelve highest-ranked programs felt to be most effective in preventing dropout. One principal had a unique community/school partnership tutoring program, and the other principal named only one of the top twelve as being most effective.

All six principals perceived that their buildings' students had a wide range of abilities, one felt that a large percentage of students came from dysfunctional families, two mentioned low socioeconomic background while one mentioned average-to-high socioeconomic background, three mentioned attendance as a problem, two identified low self-esteem as a factor, two mentioned academic achievement, and two mentioned illegal substance abuse. Poor study/work habits, lack of self-confidence, and being bused in were mentioned only once as personal identifying characteristics of potential dropouts.

Environmental factors describing their schools included: wide curriculum choices, schools within schools, parent involvement, and in-house progressive discipline. Many factors listed in the table included specific courses or programs derived from effective prevention policies including: a building mentor program, a big brother/big sister program, and a freshman camp. 
The size of the schools ranged from 480 to two schools at 1300 FTEs. The dropout rates computed for these schools ranged from -59 to 41 percent. Two schools were in economically stable communities, three were in economically inflated communities, and one was in an economically deflated community. Out of the six principals interviewed, five were male and one was female.

School Number One. "You'll drop out of this school over my dead body." is a sign displayed in the office of the vice principal. This high school has a current enrollment of 1,120 students in a suburban setting. The school has a low dropout rate at 7 percent and ranked in-house progressive discipline, a written building attendance policy, and in-building alternative programs as the most effective in preventing dropout.

Because students are on a trimester system, they have more elective choices as well as three different opportunities each year to make a fresh start. Their philosophy is that every student gets a chance to be part of a team. Athletes are not cut from teams in any sport at any level. General teams involving academic competition are open to most students and include: a math team, computer team, knowledge bowl, and academic decathalon. Students with developmental, physical, or mental disabilities are served by a special program. About 150 
Capital students serve as aides who tutor and befriend special students.

The school was designed with the "school within a school" concept. Each of the four "pods" becomes a home base for students assigned there. These pods contain the student's locker, adviser, counselor, and attendance secretary. Although the school was built in 1975, it appears to be much newer; according to the vice principal, the walls have not been painted in fourteen years and still are in good condition.

This school's discipline policy calls for immediate parent contact when a student is disruptive so that the school and home can plan together; the vice principal believes that they are proactive rather than reactive. He also believes that caring and being goal-oriented keeps the students on track through their junior year; then the students experience a phenomenal success rate. The school believes in giving their students a lot of opportunities but also in holding them accountable.

All recommended freshmen are tracked for study skills class where they are mothered, monitored, and tutored with continued home communication. The school also actively recruits volunteers for these classes. Although the students are not all college material, that is what is pushed and promoted. 
It appears that this school and its staff make positive use of the personal and environmental variables to promote staying in school to graduation. They actively use an in-house progressive discipline program, the program felt to be most effective by the respondents. The staff is proactive in communicating with the parents and in establishing a school environment where all students are safe, secure, and evidently felt wanted and important. Although the students are held accountable for their actions, this school enjoys a low dropout rate of 7 percent, 11 percent below the state average. This is true in their current position of declining enrollment, which often results in a higher than average dropout rate. School Number Two. The principal was initially interviewed in his office and later while he and the researcher walked around the building. The school is in an urban area and lists 900 students as its enrollment. The principal thought that freshmen bonding programs, small-group advisories, in-building alternative programs, and vocational programs were the most effective in preventing dropout. The school was selected because of its geographic setting, size, and more information was sought on the programs ranked most effective.

The freshman bonding program consists of sophomores assigned as big brothers or big sisters to incoming 
freshmen. This deals with personal / psychological variables such as social integration and self esteem within the school environment. The purpose of the program is to help the underclassmen "learn the ropes" with scheduled activities during first semester. After this, nothing formal is planned but it is hoped that bonding has taken place by this time.

In conjunction with the bonding program, staff desiring to do so provide a mentorship program for at risk students. Each participating staff member takes one or two students "under their wing" while they are at school. This was felt to be effective first semester. Both the bonding program and mentorship program were begun in the 1988-89 school year and both are appear to deal with making the environmental variables at school positive to enhance the personal / psychological variables of the students in an attempt to prevent early school leaving, the behavior variable.

In addition, they have had a very active on-campus drug intervention team since 1986. This consists of an administrator, counselor, teachers and students; they meet on an on-call basis several times a month. For students who have left school because of drug use, they have an after care program taught by a school nurse when the students return. This is probably one of the only examples 
of the interaction from the behavioral variable, dropout, to the environmental variables of the school as well as nurturing some of the personal variables such as self esteem. Another example of this is Project Regroup coordinated by a dropout specialist. The specialist deals with the parents of the identified dropout as well as community members to find ways to get them back in school. His emphasis is on the work ethic and reportedly has a great ability to of interacting with all kids.

This school also has some very strong vocational programs, of which one is a radio and television program. In fact, this school is a magnet school in the urban area for television communications and horitculture. The principal feels that there is a lot of potential here and can be further utilized through media coverage and promotion.

Finally, in 1989, they hope to begin small group advisories with 12 - 15 freshmen per staff member. Staff will become advocates for students and help with scheduling and counseling. Specific functions will be scheduled once a week to develop interpersonal relationships, a specific example of working with personal variables within the school environment to achieve positive behavior. Despite these programs and plans, this school had a higher than average dropout rate. The principal feels the 
main reason for this is socioeconomic level, and the disintegrated family. With a history of non-achievement, some students begin skipping classes, miss credits, are retained a grade or grades, and finally give up. As research has reminded the reader, there are some things that the school cannot change. However, it appears that this school is trying to improve the environment of the school to fit the personal needs of the students; perhaps their dropout rate would be still higher if it were not for these programs felt to be effective.

School Number Three. This school is located in a suburban setting south of Seattle and currently has 1,300 students. This school was visited because more information was sought on its after school study program. The principal felt that their in-building alternative programs, in-house progressive discipline, vocational programs, and written building attendance policy were the most effective preventatives to dropout.

Their Study Program responds to the personal problems of: weak/poor study habits, lack of motivation and self discipline, and a lack of confidence with low self esteem. The objectives are to correct these factors and to improve students' effectiveness in their required academic subjects and to decrease the number of potential dropouts from the school. The SP is scheduled for Tuesdays and Thursdays 
from 2:30 - 4:00 in a designated classroom. Coursework consists of 30 minutes of instruction the basic skills and one hour of supervised study with assistance for regular homework. Students failing two or more core classes at the end of third quarter are strongly encouraged to participate in this program. Communication is made with the parenis in regard to this program and the need for their student to participate. The school environmental factors have been enhanced to meet the personal needs of the students through this program, and the principals believes in its effectiveness to reduce the number of dropouts because of its prior success at another Washington high school.

School Number Four. This high school is located near a nuclear submarine base. The school is in a suburban area, is enjoying economic inflation, and houses 1,050 students in grades 10 - 12. It was selected because of its negative dropout rate (more students graduated than there were incoming freshmen four years earlier) and because of its academically at risk tutoring program, Tutoring and Intervention for Every Student (T.I.E.S) Partnership (Apostle, 1989). A partnership has been created with the crews of the U.S.S. Georgia SSBN 729 that has resulted in a very successful tutoring program. Along with the 51 tutors recruited from the submarine, 15 tutors are available from the Naval Undersea Warfare Engineering Station in Reyport; 
and six private citizen tutors from the city participate as well.

Along with an enviable negative dropout rate, tutored students experienced an increase in class grade point averages as a result of T.I.E.S., tutored students decreased less than untutored students in semester grade point averages, and tutored students demonstrated a higher first and second semester attendance rate than untutored students.

This school has appeared to maximize the environmental variables in the community and in the school to maximize the personal potential of its students, specifically by improving academic achievement and attendance. The dependent variable dropout rate is computed at being non-existent. While it is significant to remember that the demographic variable, economic stability, ha', shown to be a significant factor in dropout rates, it is diffisult to argue with the reported success of the T.I.E.S. program.

School Number Five. This high school. was selected because of its urban setting, its female principal (only 9 out of 96 respondents were female), the large enrollment (1,300 students), the fact that child care was listed as the most effective dropout program, and that the school was training to become an outcome based education school. 
While the school has an above average dropout rate, many programs are felt to be effective in the rate not being higher: child care/teen parenting program, out-of-building alternative programs, in-house progressive discipline, drug and alcohol after care classes, and outcome based training.

The teen parenting program houses a day care center that meets two periods a day: third period and then lunch with the student's child. The principal, feels that it is good for everyone at the school as the participating students learn how to properly care for their child and observers see the work involved. This program has fifteen students and deals with the personal factor of pregnancy within the school environment, allowing the young parent to more easily continue his or her education.

The principal also established an in-house discipline policy entitled "Students Rights and Responsibilities." Over the past four years, student management has been markedly improved, reducing 60 appeals a year of people who had been suspended, to one appeal in the last year. This is interpreted as reducing behavioral problems, another personal factor characterizing potential dropouts. The emphasis currently is using william Glaser's theory for reality therapy in connection with outcome based education. The belief system of this philosophy includes: 
All students can learn: the school controls the conditions for success; mastery learning is the foundation; and curriculum alignment is a tool. Personal variables (low self-esteem) and school environmental variables (school ineffectiveness) are dealt with positive behavior (no dropout and improved achievement) as the goal.

School Number Six. This school was selected because of its rural setting, small size, its average dropout rate, its high ranking of vocational programs, and its mention of the WTI program.

The principal feels that although there are $10-20$ percent of each class that go to college and successfully complete their university education, there is also a demand for vocational training in the school so that students may go directly to work after graduation. He feels that the vocational programs in the high school are successfully serving the students while in school, and in many cases keep the students in school to graduation. Vocational programs deal with personal variables of finding classes that particularly interest students within the school environment. These programs also are instrumental in preparing the students for jobs in the community environment, and in most cases providing for the desired behavior of staying in school. 
This school has had a Washington Teen Institute (WTI) program for two years. WTI is a primary prevention program for high school and junior high students with the goal of using peer pressure to create a positive influence among their peers that encourages abstinence from alcohol and other drug use and abuse. The program components are to: provide education in alcohol and other drug abuse; promote positive modeling through self esteem and leadership skills; develop a student run prevention program; identify, utilize and inform community resources; and provide followup and evaluation methods. In the two years that the WTI has been operated as a daily one-hour class, it is felt to be effective. This program also interacts with environmental variables (illegal drugs and alcohol) that can affect the personal factors and behavior of students.

\section{SUMMARY}

This chapter has presented the data collected by means of the five-part questionnaire sent to one hundred fifty randomly selected high schools in the state of Washington and by means of visits to six of those respondent principals granting interviews. The data was organized according to the research questions and was presented on that basis. 
The data relevant to the first part of the primary research question gave information on what principals felt to be the most effective preventative measures, intervention programs or student services in reducing dropout rates. Data relevant to the second part of the primary research question gave information on whether the availability of those services and programs accounted for a significant difference in the actual dropout rates of the sample schools.

The data relevant to the first part of the second research question gave information on what principals perceived the identifying personal / psychological characteristics to be of potential dropouts. Data relevant to the second part of this question gave information as to whether these characteristics accounted for a significant variance in the actual dropout rates of the sample schools. The data relevant to the first part of the third research question gave information on what environmental factors principals perceived to influence dropout rates in their schools. Data relevant to the second part of this question gave information as to whether these factors actually accounted for a significant variance in the sample's dropout rates.

Information for the fourth research question gave a reporting of what intervention programs or student services 
are available in either the district or high school buildings of the sample surveyed.

Data relevant to the fifth research question gave information on which demographic factors in the sample schools significantly affect dropout rates. 


\section{CHAPTER V}

SUMMARY, CONCLUSIONS, RECOMMENDATIONS

\section{SUMMARY}

This current study examined what available preventative measures, intervention programs or students services are perceived to have prevented dropout. The study also examined personal / psychological factors characterizing potential dropouts, environmental factors inluencing dropout rates, the availability of intervention programs or students services, and the demographic factors significantly affecting dropout rates in the state of Washington.

The pursuit of this topic comes at a time when much has been written about the causes of dropout and a myriad of recommendations have been made to reduce dropout trends reported across the state and nation. While a variety of new programs have been reported in several states and new approaches and programs are being introduced in buildings and districts every year, few reports based upon the literature review of what was perceived to be most effective at this point had not been found. Because one recommendation of reducing school size (Barker, 1986; Jess, 
1985) was not found to be characterized with low dropout rate, it was of importance to find what recommendations are felt to be effective.

Since dropout behavior was believed to be a product of both personal / psychological factors and environmental factors, the theoretical framework utilized in the study was the Social Cognitive Theory (Bandura, 1986); this framework incorporates the triadic reciprocal design where personal factors, environmental factors, and behavior all interact with each other. The research questions, then, also considered these personal and environmental variables to determine if those variables significantly affected dropout rate.

\section{Primary Question}

1. (a) What preventative measures, intervention programs or student services designed to enhance environmental and personal factors are perceived to have reduced dropout rates in the sample?

(b) Does the availability of these services and programs account for a significant difference in the actual dropout rates? 


\section{Secondary Questions}

2. (a) What personal / psychological factors characterize potential dropouts?

(b) Do these identifying characteristics account for a significant variance in the actual dropout rates?

3. (a) What environmental factors influence dropout rates in the schools?

(b) Do these factors account for a significant variance in the actual dropout rates?

4. What intervention programs or student services are available in the sample?

5. What demographic factors in the sample schools significantly affect dropout rates?

In order to answer these research questions and to draw conclusions about the perceived effectiveness of programs and services designed to reduce secondary student dropout rates, surveys were mailed to a random sample of high school principals from all (303) public high schools in the State of Washington. Sixty-four percent of the principals responded. Followup visits were made to six high schools to collect further information about their schools' programs. Conclusions were drawn based upon both the quantitative and qualitative data thus obtained. 


\section{CONCLUSIONS}

The answers to the research questions posed in this study led to some conclusions regarding what programs are perceived to be effective and if they account for a variance in the actual dropout rates, what personal and environmental factors are perceived to interact and actually affect dropout rates, and what demographic factors significantly affect dropout rates. Although no previous dropout studies were found using Bandura's theory, it appears to have the foundation for explanatory power. Specific conclusions within this framework follow.

What preventative measures, intervention programs or student services designed to enhance environmental and personal factors are perceived to have reduced dropout rates in the sample?

Eighty seven respondents ranked the following programs as perceived to be most effective in preventing early departure from school. From the field test of the survey, teachers' caring and concern was volunteered as one of the most effective deterrents to students" dropping out. However, surprisingly this was not even suggested in this present study. Responses such as "effective counselors" or "a particularly outstanding teacher" were volunteered but not enough to be classified as the most effective.

Those perceived to be the most effective are listed starting with the most effective program and the top twelve 
are discussed. Four of the six principals interviewed ramed at least three of these programs as the most effective in preventing dropout. One principal had a very effective tutoring program, and the other principal only named one of these as most effective.

In-house progressive discipline. This was perceived to be the most effective deterrent to students' dropping out of school. Schools visited by the researcher also had this program/policy ranked in the top three although the exact policy may vary from school to school. Prior to the use of in-house progressive discipline, students were suspended from school often giving them the feeling of a "vacation" from their responsibilities at school. Suspension, and in severe cases, expulsion from school did not reinforce the importance of attending and being responsible at school.

With the implementation of in-house progressive discipline, policies were written, staff was trained, and students were given the rights and responsibilities of succeeding in school. Personal, environmental and behavioral determinants all interact in these situations. While the students and staff members need to be accountable, the message says that the school cares about the student and wants them to learn while they are there. It was concluded that this student conduct policy is 
perceived to be effective by the respondents in reducing dropout rates.

Vocational programs. These programs introduce specialties to students that appeal to their personal interests and often their natural abilities and skills. In addition, they offer an immediate reward upon graduation from school by preparing students for a job in their community environment. Although they have not yet gracuated, students may have observed upper classmen who have had vocational training, have graduated, and are now successfully employed and receiving paychecks. This observed behavior is termed a vicarious motivator and is an example of the interaction between behavior and personal factors.

The vocational classes also provide practical and hands-on experiences within the school environment that appeal to some students' personal interests. While college-bound students also take vocational courses, these classes often provide at last a place where some students feel they belong when perhaps they are struggling with core academic classes. In these cases, the school's environmental factors are interacting with the students personal needs. Finally, vocational classes have active community advisory committees, so that the school environment is interacting with the community environment, 
in most cases making the curriculum up-to-date and meaningful.

Written building attendance policy. This usually consists of a standardized policy that lists what should be pre-arranged, what will be excused and unexcused, the timeline for making up assignments, and how credit will be earned or lost after a number of absences. For instance, one district has a policy that does not allow semester credit after thirteen absences. This is interpreted as an environmental factor that gives a message that it is important for the student to be at school and is perceived to be particularly effective if the administrative and instructional staff indicate that the student is missed when she or he is absent, appealing to the student's personal need of being recognized and cared about. Schools with an aggressive attendance policy usually have an attendance officer who calls the parent at home or work to indicate the student's absence and to show concern and interest in the student's being at school. This would occur when the student's absence has not been pre-arranged. This again is an example of the interaction between personal, environmental, and behavioral factors and is believed to contribute to dropout prevention. Out-of-building alternative programs. Examples of these programs would be alternative schools, skill centers, 
and some child care/teen parenting programs. While these programs take some students out the regular building, these alternative programs can provide preferable environments that meet their particular personal needs while their education is continued. In addition, the students remaining in the regular building may sometimes have an improved school environment, particularly if a chronic disruptor has chosen to select an alternative program in another building.

Cooperative work programs. The philosophy under vocational programs applies here in addition to taking the interaction of personal interests and school curriculum further through interaction with jobs in the community environment. Students may receive school credit by working part-time at a job under the supervision of a school staff member and in coordination with the business where the job is held.

Freshmen bonding programs. These programs have been established in consideration of the needs of the young newcomers to a high school. By providing bonding within the school environment and with upperclassmen, it was concluded that the freshmen will understand the educational as well as the social process of the school and feel that he or she is an important part of the system. 
Small group advisories. These small groups are assigned, usually in the freshman year, to a teacher or counselor. The groups create "families" within the larger school environment where students hopefully feel

comfortable and are provided an advocate through the staff person in their advisory. It was concluded that a variety of personal needs can be handled during "advisory" and study time is often available as well.

In-building alternative programs. The same philosophy exists here as in the out-of-building alternative programs except there are classrooms or wings to accommodate the personal needs of exceptional students.

Written district attendance policy. While the building attendance policy (ranked third) is considered more effective, it was concluded that the district's commitment to student attendance further reinforces the building's efforts at keeping students in school.

Required life skills class. Although the curriculum for this class may vary in different schools, the similarities are more prevalent. The class deals with most of the personal factors characterized with potential dropouts: weak or poor study skills, weak or abusive family structure, history of low achievement, low self esteem, personal interrelationships, positive and negative peer influences, in addition to good health practices, 
personal finance, and nutrition. It was concluded that this class enables the student to acquire skills in taking control of his or her life and to more effectively interact with the school and community environment.

Honors courses. These classes are usually offered to the highest academic achievers in grades 10,11 , and 12 . Students are either tracked into honors courses or may apply by taking an entry exam. Some schools designate honors courses on transcripts and many of these courses may enable students to enter college with advanced placement. It was concluded that these classes serve the personal interests of these students and provide curriculum within the school environment that meet those personal needs, perhaps preventing boredom and early leaving of school. Alcohol/drug-related programs. While this was scarcely mentioned in the dropout research literature and was not one of the twenty programs to be included on the survey instrument, respondents ranked alcohol / drug-related programs as the twelfth most effective in preventing permanent dropout. The word permanent is used because in some instances, schools have provided after-care programs for students who have dropped out, have gone through rehabilitation (either out-of- or in-school), and have returned to school. This is one example of the bidirectional interaction between behavioral factors and 
personal factors, and between behavioral factors and environmental factors. There are also prevention and intervention programs such as Washington Teen Institute and Natural Helpers. It was concluded that these programs deal with personal / psychological factors and environmental factors to assist the student in getting back on track to complete his or her education.

Does the availability of these services and programs account for a significant difference in the actual dropout rates?

of those available programs provided by the buildings and districts, monetary incentives accounted for only three percent of the variance in total dropout rates. When the programs were tested by multiple regression with girls' dropout rates, child care facilities accounted for three percent of the variance in dropout rates. Because the correlation was less than .205 , even this small variance could be due to chance. However, one of the interviewed principals felt that their child care / teen parenting program was the most effective program. When the programs were tested by multiple regression with boys' dropout rates, English taught as a second language, honors courses, and parent effectiveness accounted for 12.4 percent of the variance in dropout rates. While the monetary incentive was a surprise and is not a widely used incentive, it does appeal to the personal and immediate interest of most 
students. This program enhances the school environment for students regularly attending class and improving grades /or achieving good grades.

The other programs accounting for a variance also deal with personal / psychological factors by personalizing the school environment to meet specific student needs. Because of the low percentage of variance accounted for, it was concluded that other programs and variables must also be considered in accounting for the variance in dropout rates.

What personal / psychological factors characterize potential dropouts?

While the respondents agreed with research regarding identifying characteristics of potential dropouts on ten factors, the respondents disagreed on two points. The respondents agreed that teen pregnancy is a cause for dropout; however, they disagreed that it would be a reason in their school. The conclusion drawn here was that they felt committed to all students' completing their education and would continue to welcome pregnant teens at school. The respondents also disagreed that working full-time characterized potential dropouts. This characteristic accounted for only a small percentage in the variance, although it was an indicator in all three categories of dropout (total, girls and boys). None of the principals 
mentioned this factor during their interviews, although three mentioned a related factor, socioeconomic background.

Do these identifying characteristics account for a significant variance in the actual dropout rates?

while research studies indicate that working full-time would eventually be a cause for dropout, the respondents disagreed. The research was reinforced when the personal factors were tested by multiple regression with dropout rates. Working full-time accounted for only 6.8 percent of the variance, while low self-esteem, and parents' background accounted for only 2.9 and 2.8 percent respectively.

When girls' personal factors were tested by multiple regression with dropout rates, low grades, teen pregnancy, working full-time, and being a racial minority accounted for a cumulative 14.6 percent of the variance. When boys' personal factors were tested by multiple regression, working full-time accounted for only 4.5 percent of the variance. In all three tests, working full-time was shown to be an indicator of potential dropout, although the percentage of variance was low.

It was concluded that as the students' personal needs become more satisfied in the working environment, the school environment may become less rewarding and less important to the student. It may be for this reason that 
vocational programs, cooperative work programs, and skill centers are felt to be effective in preventing dropout.

What environmental factors influence dropout rates in the schools?

It was concluded that the respondents feel that stay-in programs, encouraged activities involvement, positive teacher/student relationships, parent / teacher / student policy-making, and a wide curriculum for all types of students are positive environmental factors and that they feel they are present in their schools. These opinions were repeated by the principals interviewed. All of these activities are interactional rather than one-dimensional; they each consider the students' needs and interests, the schools' goals and system, and the rights and responsibilities therein. When constructive interaction between personal, environmental, and behavioral factors occur, dropout rates should decrease. If a school's dropout rate is 30 percent, the researcher speculates that it might be 40 percent if it were not for attention to students' personal needs through school programs and services.

Further, the respondents strongly agreed that despite signs of potential dropout, some students do continue to graduation. It was concluded that this is directly 
attributed to the schools' environment, programs, and interaction with the students.

Do these factors account for a significant variance in the actual dropout rates?

The importance of active interaction between personal, environmental, and behavioral factors cannot be over-emphasized. When environmental variables were tested by multiple regression with total dropout rates, girls" dropout rates, and boys' dropout rates, this interaction was found as an indicator each time.

High parent and community involvement with the school accounted for 12.6 percent of the variance in total dropout rates, for 9.3 percent of the variance in girls' dropout rates, and 6.7 percent of the variance in boys' dropout rates. While the percentage of variance is still low, it was the only environmental factor found to explain a variance for total dropout and boys' dropout rates. Self-esteem classes and small-group advisories also accounted for 3.1 percent of the variance in girls' dropout rates, and educational excellence reform activities inversely accounted for 2.4 percent of the variance. Using the triadic reciprocal design, the high parent and community involvement with the school is interpreted as follows. Schools that place a high degree of importance on the students' being at school and students' completing 
their high school education actively communicate with parents and patrons of the community. In some cases, schools and community organizations establish partnerships as illustrated by the T.I.E.S. program at School Number Four. The symbolic behavior of graduating from school becomes an important vicarious motivator to the student; through interaction between the students' personal needs and the environmental programs and partnerships established to meet those needs, it was concluded that dropout rates are lower in the schools where this occurs than in the schools where the interaction is absent.

What intervention programs and student services are available in the sample schools?

The results of this question are shown in Table XXV in Chapter IV. While in-house progressive discipline was one of the policies to be ranked in its perceived effectiveness, it was not included in this section of the survey instrument. Rather, it was included in the environmental factors section. Considering the other policies, programs, or services that deal with the interaction between personal, environmental, and behavioral factors discussed, a large number of buildings reportedly are utilizing these practices. One hundred percent of the respondent principals reported having a written attendance policy; 96 percent have vocational programs; 81 percent 
provide cooperative work programs; 79 percent offer honors courses; and 74 percent include freshmen bonding programs. However, only 48 percent reported having in-building alternatives, 38 percent having life skills classes, 33 percent having small group advisories, and five percent using monetary incentives. A variety of available programs were ranked differently by the respondents and those ranked the most effective overall may not be the most effective for a specific area, building, or student population. One of the principals interviewed felt that their child care/ teen parenting program was one of the most effective dropout preventions; nevertheless, it was not one of the top-ranked programs and only 11 percent of the respondent buildings reported having child care in their school.

It was concluded that while many schools are addressing the dropout problem and are attempting to adjust their school environment through effective programs, policies, and services, the perceived need for or effectiveness of some of the programs is not universal for this sample.

What demographic factors in the sample schools significantly affect dropout rates?

While demographic factors give descriptions of the community and school environments, for the most part they are just that; it is felt that most of the factors cannot 
be adjusted by school administrators or staff to personally meet the needs of the students. The results of the analyses of variance of demographic variables with dropout rates is shown in Table XXVII.

Geographic setting, size of school, per pupil expenditure, and the age of principal were not found to be significant in explaining the cause for dropout. Although there was a significant finding when an analysis of variance was done on gender of principal, $F(1,87)=9.791$, $\mathrm{p}<.05$, the researcher felt that there were other factors that could influence this. First, only nine female principals responded as compared to 80 male respondents; and second, considerations of principal placement might want to be considered. Because these considerations go beyond the scope of this study, no further conclusion of female principals having significantly lower dropout rates at their buildings than male principals was made.

An analysis of variance examining economic stability of the surrounding community with dropout rates was found to be significant, $F(2,86)=3.46, p<.05$. The 23 schools reporting the surrrounding community as inflated had a significantly lower mean dropout rate $(4.5$ percent) than the 41 economically stable (21.6 percent) or the 32 eonomically deflated schools (25.2 percent). Further, it was found that there was a significant difference between 
the inflated communities' dropout rates and the stable community, $F(1,86)=4.609, p<.05 ;$ and a significant

difference between the inflated and deflated communities, $F(1,86)=6.355, p<.05$.

An analysis of variance also examining the use of the free school lunch program with dropout rates was found to be significant, $F(1,87)=4.169, \mathrm{p}<.05$. Schools with less than 24 percent of their students using this program had a mean dropout rate of 13.9 percent while schools with more than 23 percent using the program had a mean dropout rate of 27.1 percent. Because this implies that there may be a correlation between the economic stability of the surrounding community and the need for school lunch assistance, similar conclusions were drawn for the schools from economically inflated communities and those schools with less than 23 percent of the students using the free school lunch program.

At first, it might be concluded that if the school is not in an economically inflated community, any specific efforts to keep all students in school would be futile. It is true that it appears to be easier in an inflated community; in fact, schools in these areas often reported negative dropout rates (more students graduating than incoming freshmen four years earlier). Effecting tracking of specific students goes beyond the scope of this study 
(see Chapter I), but a school in an inflated community could actually be losing 25 percent of its original students and it would go unnoticed because of an influx of 30 percent new students moving into the district and building. Three of the schools visited reportedly had econmically inflated surrounding communities; however, their dropout rates were calculated at: $41,-59$, and 33 percent.

Because of the earlier environmental factors shown to be effective in accounting for a variance in the dropout rates, it was concluded that it is the effective interaction between the personal, environmental, and behavioral (symbolic or actual) factors that will improve a school's graduation rate rather than sole reliance on the economic stability of the surrounding community. Without consideration of and interaction with the personal needs of the students in the above schools, it is speculated that the dropout rates might hive calculated at: $51,-49$, and 43 percent.

\section{RECOMMENDATIONS}

1. The twelve policies, programs, and services perceived to be most effective should be considered for implementation in schools where they are not used but felt to be appropriate and should be maintained, supported, and 
improved in the buildings where they already exist and are felt to be effective in assisting the student population.

2. Monetary incentives, child care facilities, Erglish taught as a second language, honors courses, and parent effectiveness programs should be considered for implementation in schools where they are not used but felt to be appropriate and should be supported and enhanced in the buildings where they already exist and are felt to effectively serve the student population.

3. Personal/psychological factors accounting for a variance in the dropout rates including: working full-time, low self-esteem, parents' background, low grades, teen pregnancy, and being of a racial minority, should be carefully considered by committees and management teams when establishing curriculum, new classrooms or buildings, programs, services, or policies within the school environment or in partnership with the environment at large, the community.

4. Environmental factors accounting for a variance in the dropout rates: high parent and community involvement with school, and self-esteem classes and small group advisories, should be encouraged, implemented, maintained, and improved. While the education excellence reform has had some positive impacts, it is further 
recommended that the reform is excercised carefully so that it constructively reaches all students.

5. Using Bandura's reciprocal determinism as a model, maximize the positive possibilities through constructive interaction with the community, school, and students to prevent early school leaving and to reduce dropout rates. In an economically deflated area, one example of interaction would be to establish a cooperative / partnership with a church, government agency, or small business where students might work without pay but for school credit. This would positively heip the community and would help the student apply his or her skills while gaining experience.

\section{RECOMMENDATIONS FOR FURTHER RESEARCH}

1. Further studies using Bandura's social cognitive theory could supply more information with which to answer whether the reciprocal determinism (interaction between personal, environmental, and behavioral factors) is an effective theory on which to base the prediction of school dropout rates.

2. Using Bandura's model of triadic reciprocal determinism, a study considering other personal and environmental factors: age of students assessed, perceptions of students and teachers, caring and concern of 
teachers, and perceptions of counselors to account for the remaining variance in dropout rates.

3. A study of intervention programs at elementary and middle schools for at risk students prirs to their high school career.

4. A study on schools that have established school/community/parent involvement and partnerships to compare previous dropout rates with current and future dropout rates.

5. A study on schools in communities where economic stability has changed to see if a significant variance in dropout rates follows. When studying the economic stability of communities, it is further recommended to find the ranges of dropout rates in the inflated communities, the stable communities, and the deflated communities and compare those ranges.

6. A study on the probability of improving the interaction of different socioeconomic groups, specifically when the socioeconomic group of the educational staff is felt to be considerably different than that of the families of the students in the school.

7. A study on student-initiated programs within the school or community.

8. Further study on the gender-related educational leadership issue to include: numbers of females and males 
in principal and superintendent positions, issues discussed when selecting a female or male for these roles, and an examination of dropout rates and achievement outcomes when females or males serve in those leadership roles. 


\section{REFERENCES}

A prototype occupational choice model for disadvantaged youth in rural schools. (1981) Austin: Texas Education Agency. ERIC Document Reproduction Service No. ED 234177.

Apostle, T. (1989). The development and assessment of a school-community partnership tutorial program for academically at-risk secondary school students. Jnpublished doctoral dissertation. Washington state University, Pullman.

Arias, M. B. (1984). Paper presented at at the George I. Sanchez Seminar. The status of educational attainment of Chicano/Mexican students. Berkely: University of California.

Ary, D., Jacobs, I., \& Razavieh, A. (1985). Introduction to Research in Education (3rd ed.). Holt, Rinehart and Winston: New York.

Austin Independent School District. (1983). A study of dropouts. Austin, Texas.

Bandura, A. (1986). Social foundations of thought and action. Englewood Cliffs, New Jersey: Prentice-Hall Inc.

Barker, B. (1986). The advantages of small schools. Las Cruces, NM: New Mexico State University, ERIC Clearinghouse on Rural Education and Small Schools. (ERIC Document Reproduction Service No. ED 265 9881)

Barr, R. D. ( $i, 8)$. At-risk youth--at last a problem we could solve. The Bridge, $1,(1), 1-2$.

Billings, J. A. (1989). Superintendent's message. Your Pub?ic Schools, 28, 2 .

Blum, M., \& Spangehl, S. (1982). Developing educational programs for the high risk secoindary school and college student. New York, NY: ERIC Clearinghouse on Urban Education. 
California state Department of Education. (1983). Raising expectations: model graduation requirements. Sacramento, California.

California State Department of Education. (1986). California dropouts a status report. Sacramento, California.

California Assembly office of Research. (1984) . Dropping out losing out: The high cost for California. Sacramento, California.

Camp, C., Gibbs, J., \& Monagan, M. (1980). School dropouts - A discussion paper. California Legislature. Assembly Office of Research, Sacramento, California.

Cervantes, R. A. (1982). Hispanic underachievers: the neglected minority. Paper presented at the Hispanic English Dominant Student Conference. SDSU NOD Lau Center. Anaheim, California.

Conrath, J. (1986). Dropouts descend from the discouraged, defeated. The Oregonian, p. C1.

Cox, J., \& Spivey, R. (1986). High school dropout in Appalachia: problems and palliatives. Research Triangle Park, NC: ERIC Document Reproduction Service RC 015 856. Research Triangle Institute.

Dropout rate nears 20 percent in state. (1989, January). The Columbian, p. A6.

Dropout woes start early. (1989, May). The Columbian, p. B4.

Edmonds, R. (1979) . Effective schools for the urban poor. Educational Leadership. 37(1), p. 15 .

Education USA. (1986). Dropouts: Who and why? National School Public Relations Association, 28, (19).

Ekstrom, R. E., Goertz, M. E., Pollack, J. M., \& Rock, D. A. (1986). Who drops out of school and why: findings from a national study. Teachers College Record, 87, 356-373.

Fine, M. (1986). Why urban adolescents drop into and out of public high school. Teachers College Record, 87, 393-409. 
Flax, E. (1988, March 2). Cashing in on school. Education Week. p. 24-25.

Goetz, J., \& LeCompte, M. (1984). Ethnography and qualitative design in educational research. Orlando: Academic Press, Inc.

Gottfredson, G. (1981). Schooling and delinquency prevention: Some practical ideas for educators, parents, program developers, and researchers. (NIE-G-80-1131). Washington, DC: National Institute of Education.

Greenwood, S. (1988). A study of school size and its effect on dropout rate. Unpublished manuscript. Portland State University, School of Educational Leadership, Portland, Oregon.

Hodgkinson, H. I. (1985) . All one system: demographice of education, kindergarten through graduate school (ISBN 0-937846-93-7). Washington, D.C.: Institute for Educational Leadership, Inc.

Hodgkinson, H. L. (1988). The right schools for the right kids. Educational Leadership, 45, (5), 10-14.

Jess, J. (1985, August). Local leadership and quality rural education. Paper presented at the National Rural Education Forum, Kansas City, MO.

Keeping students in school. Dropout data, research, and programs. (1985). Raleigh: North Carolina State Department of Public Instruction. ERIC Document Reproduction Service No. ED 265430 .

Kessler, G. (Editor). (1986, December). At-Risk Newsletter. (Available from Gary Kessler, Springfield Public Schools, 525 Mill Street, Springfield, Oregon).

Kolstad, A., \& Owings, J. (1986, April). High school dropouts who change their minds about school. Paper presented at the annual meeting of the American Educational Research Associaìion, San Francisco, CA. 
Los Angeles Unified School District. (1985). A Study of Student Dropouts in the Los Angeles Unified School District. Los Angeles, California.

National Commission on Secondary Education for Hispanics. Make something happen. (1984). Hispanics and Urban School Reform. Washington, D.C. Hispanic Policy Development Project, Inc.

Pallas, A. M., \& Verdugo, R. R. (1986). Measuring the high school dropout problem. Washington, D.C.: U.S. Department of Education.

Pallas, A. M. (1987). School dropouts in the United States. (CES Publication No. 065-000-00276-1). Washington, DC: U.S. Government Printing Office.

Parsley, J. (1989). Progress on secondary at-risk students. Final report on the implementation of Vancouver school district goals for 1988-89. 24-50.

Perpich, R. (1989, March). Invest in youth today, or pay the consequences (Editorial). The Oregonian, p. B9.

Pittman, R. B. (1986). Importance of personal, social factors as potential means for reducing high school dropout rate. The High School Journal, 70, 7-12.

Raeburn, P. (1987, February 16). School dropouts now include brightest. The Oregonian. p. Al6.

Rumberger, R. H. (1983). Dropping out of high school: the influence of race, sex, and family background. American Educational Research Journal, 20, 199-220.

Rumberger, R. W. (1987) . High school dropouts: a review of issues and evidence. Review of Educational Research, 57(2), 101-121.

San Diego City Schools. (1985). The 1982--83 school leaver study of the San Diego Unified School District. Research Department Report. San Diego, California.

Sisson, B. (1989, January 10). Battle Ground school board oks middle-school social skills plan. The Columbian, p. A3. 
Smith, M. E. (1987). Equality of educational opportunity for language minority students in Oregon: A survey of ESL/bilingual education policy in local school districts (Doctoral dissertation, Portland State University, 1987). Dissertation Abstracts International, 49,691 .

Staff. (1988, April). At risk kids go to work. Torch, p. 1 .

Staff. (1989, January). Modeling real life job experiences. Torch, p. 1 .

Stasiowski, J. (1989, February 13). Ridgefield keeps dropout rate low. The Columbian, p. A3.

Steinberg, L., Belinde, P., \& Chang, R. (1982) Dropping out among language minority youth: a review of the literature. Los Alamitos, CA: National Center for Bilingual Research.

Thompson, S. (1989, January). Dropouts hard to count (Letter to the editor). The Columbian, p. A10.

U.S. Department of Education, National Center for Education Statistics. (1983) . High school dropouts: Descriptive information from High School and Beyond (NCES 82-221b). Washington, DC: National Center for Education Statistics.

Washington Education Association. (1989). Restructuring Public Education: Building a Learnina Community (The Report of the Education Task Force). Federal Way, WA: Author.

Wehlage, G. G., \& Rutter, R. A. (1986). Dropping out: how much do schools contribute to the problem? Teachers College Record, 87, 374-392.

Youth 2000. (1988). A national campaign in support of America's youth from now to the year 2000 . (Information available from Youth 2000, Room 309F, HHH Building, 200 Independence Ave. SW, Washington, D.C.) 
Zachman, J. M. (1987). A selected review of the literature on factors and conditions driving the high risk and dropout problem. Policy studies in language and cross cultural education. San Diego: San Diego State University, Dept. of Policy Studies. ERIC Document Reproduction Service No. ED 284938.

Zobrist, I. D. (1985) - Report on dropouts done for the Washington Roundtable. Seattle, WA. Citizens Education Center Northwest.

Zuzel, M. (1987, December 16). State funds to fight dropout problem. The Columbian, p. A3.

Zuzel, M. (1988, October 12). Educators, businesses plan help for at risk students. The Columbian. p. A3. 
APPENDIX A

COVER LETTER MAILED WITH FIVE-PART SURVEY INSTRUMENT 
12501 NW 19 Avenue

Vancouver, WA 98685

(206) $573-7836$

February 14, 1989

Dear Administrator:

As a doctoral student at Portland State University in Portland, Oregon, I am conducting a survey of randomly selected secondary schools from the State of Washington. The intent of the study is to find out what qualities, services, or programs you think have been most effective in preventing students from dropping out of school.

Although many programs and services have been recommended to prevent early school departure, it is not widely known which of those services have been effective. That is the purpose of this study--to find schools with policies, programs, and practices that have reduced their dropout rates. Your response is most important to the study and invaluable for future research in dealing effectively with the at-risk youth. The survey takes about 15 minutes to complete. Because data analysis will begin early in March, return of the completed survey by February 28 will be greatly appreciated. The completion of the survey wiा al $\overline{50}$ represent your consent to contribute to the study.

No reference will be made to a particular school. Respondents will be checked off against a coded mailing list. There will be no connection between principal's responses and information collected, unless you circle "yes" on the last page. This indicates that you would be willing to grant an interview or building observation for qualitative data. Your help and participation is greatly needed and appreciated. A summary of the results will be ready mid-1989, and a copy of it will be sent to you if you so indicate on the last page.

Thank you again for your consideration and assistance with this project.

Sincerely,

Susan Greenwood, Student

Portland State University

Enclosures 2

Survey

Return Envelope 
APPENDIX B

FIVE-PART SURVEY INSTRUMENT 
State of Washington

SECONDARY SCHOOL SURVEY

FOR EACH ITEH, PLEASE CHECR ONE CATEGORY WHICH BEST DESCRIBES YOUR BUILDING.

1. The geographlc settlng 13 malnly:

Rural

Suburban

Urban

2. The current building enrollment is:

$$
\begin{array}{r}
0-500 \\
501-1,000 \\
1,001-1,500 \\
\text { Over } 1.500
\end{array}
$$

3. What do you est Imate the average number of students to be per classroom?

$$
\begin{aligned}
& 10-15 \\
& 15-20 \\
& 20-25 \\
& 25-30 \\
& 30-35 \\
& 35-40
\end{aligned}
$$

4. What do you estimate the total per pupil expenditure to be for your district?

$$
\begin{array}{r}
\text { Under } \$ 2,500 \\
\$ 2,500-\$ 3,000 \\
\$ 3,000-\$ 3,500 \\
\text { Over } \$ 3,500
\end{array}
$$

5. What do you est Imate the average household income to be for the students in your building?

$$
\begin{array}{r}
\text { Under } \$ 10,000 \\
\$ 10,000-\$ 30,000 \\
\$ 30,000-\$ 50,000 \\
\$ 50,000-\$ 70,000 \\
\$ 70,000-\$ 90,000 \\
\text { Over } \$ 90,000
\end{array}
$$

6. In considering the economic stability of the surrounding community, would you classlfy it as inflated, meaning that new Industry is evident with an Increase in new housing; stable. meaning that Industry and famlly mobllity is relatlvely constant; or deflated, meaning that there has been industry recession with a decrease in housing needs.

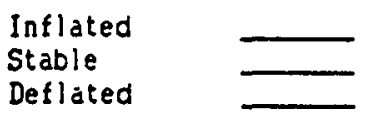


7. Gender of principal?

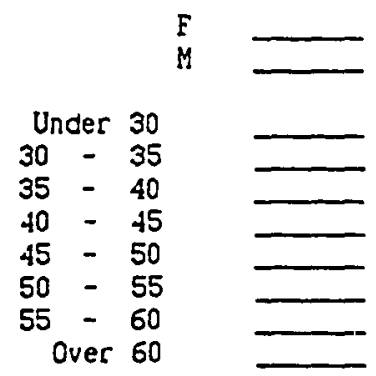

8. Age of principal?

THE FOLLOWING QUESTIONS WILL NEED AS SPECIFIC NUMBERS AS POSSIBLE TO DETERMINE SIGNIFICANCE IN THE OUTCOME OR THE STUDY. PLEASE FILL IN THE ANSWERS AS ACCURATELY AS POSSIBLE.

9. What percentage of your building's students utilize the free school lunch program?

10. What do you estimate the racial distrlbution to be of your student body? (The percentages should add up to 100.)
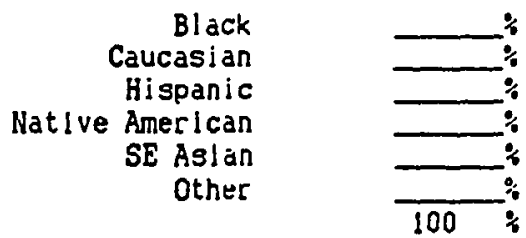

11. What is the racial dlstribution of your school bullding staff? (The percentages should add up to 100.)

$$
\begin{array}{r}
\text { Black } \\
\text { Caucasian } \\
\text { HIspanic } \\
\text { Nat Ive Amerlcan } \\
\text { SE Asian } \\
\text { Other }
\end{array}
$$

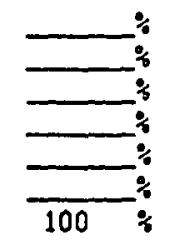

12. How many students in your bullding graduated in 1988?

Number of glols?

Number of boys? 
FROH YOUR EXPERIENCE AND OBSERVATIONS, PLEASE CIRCLE THE RESPONSE THAT BEST DESCRIBES IDENTIFICATION OF POTENTIAL DROPOUTS.

SA-Strongly Agree A-Agree D-Disagree SD-Strongly Disagree

Note: Please do not put clrcles between responses.

13. Low grades are a significant Indlcation that the student will leave school before graduation.

$$
\text { SA } \quad A \quad \text { D } \quad \text { SD }
$$

14. Raclai minorltles are more likely to drop out than whites.

$$
\text { SA } \quad \text { A } \quad \text { D } \quad \text { SD }
$$

15. Males are more llkely to drop out than females.

$$
\text { Sh } \quad \text { A } \quad D \quad S D
$$

16. Parents' education, asplratlons, and Income level are probabiy the greatest. factors influencing a student remaining to graduation.

SA $\quad A \quad$ D $\quad$ SD

17. Low achlevement scores are a strong factor in Identlfylng future dropouts.

$$
\text { SA A } \quad \text { D }
$$

18. Behavlor problems evldenced by acting out, cutting classes, and truancy are indlcators of probable dropping out.
Sh
A
D
SD

19. Low self-esteem may be a strong Influence for dropping out of school before graduation.
SA
A
D
SD

20. An Inablllty to soclally Integrate may influence early dropping out.
Sค
A
D
SD

21. Fear of gang activity may influence a student to drop out before graduation.

SA $\quad A \quad$ D $\quad S D$

22. The high school can do llttle to improve the student's self-esteem and feeling of social integration.

SA $\quad A \quad$ D

23. Teen pregnancy is a frequent reason for girls' dropplng out before graduation.

Sh $\quad$ D $\quad$ SD


24. In vur hlgh school, pregnancy would not be cause for a girl to drop out before gr aduation.

$$
\text { SA A } \quad D \quad S D
$$

25. Having to work full-time to help out the family is a frequent reason for dropping out.
SA
$A$
D
SD

26. Holding students back a grade (retention) may cause students to drop out before graduatlon.
SA
A
D
SD

27. Desplte early warning slgns of potentlal dropout, some students will succeed through to high school graduation.

SA $\quad A \quad$ D $\quad$ SD

28. Peer influence is one of the strongest forces in leading a student to drop out before graduatlon.
SA
A
D
SD

29. The total number of students in a high school makes a difference in an individual student's ablilty to soclally integrate.

SA A $\quad$ D $\quad$ SD

BOR STUDENTS THAT ARE CONSIDERED POTENTIA: DROPOUTS, SEVERAL PROGRAMS OR IMTERVENTIONS MIGHT BE UTILI2ED. FOR EACI ITEN, PLEASE CIRCLE THE RESPONSE THAT YOU FEEL BEST DESCRIBES YOUR BUILDING.

SA-Strongly Agree A-Agree U-Unknown D-Disagree SD-Strongly Disagree Hote: Please do not put clrcles between responses.

30. When teachers Identify potentlal dropouts or problems, those students are ceferred to a counselor for possible intervention.
Sh
A
U
D
SD

31. When various behavlor problems disrupt other students, disruptors are temporarlly suspended from class.
SA
A
U
D
SD

32. Our bullding has a progressive discipline pollcy e.g., the student is counseled on the first offense, counseled and some kind of on-campus work assigned for the second offense, and assigned to in-house suspension for the third offense--or a slmllar system to keep the student at school.
SA
A
U
D
SD 
33 . Oui bullalig wants to educate the students motivated to learn the al zruptors are elther temporarlly suspended from school or recommended to another school distrlet or school within the distrlet.
SA
A
U
D
SD

34. There is a large percentage of students involved in school activities such as orama, band and orchestra, athletics, and other organizations.

SA U $\quad$ D $\quad$ SD

35. Bullding dropou, ritrention programs are in place through requlred self-esteen classes or small-group advlsorles.
SA
A
U
D
SD

36. The dlstrlct provldes alternatlve programs for potential dropouts in a separate school facllity.

SA A U U D

37. There is a high degree of parent and comunity lnvolvement with our students through varlous partnershlps and contracts.
Sh
h
U
D
SD

38. It is evident that there ace positlve teacher-student relations in this building.
$\widehat{S A}$
A
U
D
SD

39. Students, parents, and teachers are encouraged to participate in policy making in this bulliding.
SA
A
U
D
SD

40. The "Excellence" reform has put some of our potentlal dropouts at further clsk.
SA
A
$\mathrm{U}$
D
SD

41. The district has the financial abillty to take prlde in building and classroom malntenance and this is a top prlority.
Sh
A
U
D
SD

t2. The curriculum Includes classes for all abllltles with resources for the gifted, handicapped, vocatlonal, and college-bound.
SA
A
U
D
SD 
43. The severely handlcapped, elther behavlorally, physlcally, or mentally, have separate classrooms in the bullding where they recelve the required curriculum.

$$
\begin{array}{lllll}
S A & A & U & D & S D
\end{array}
$$

IN THE POLLONING OUESTIONS, PLEASE CIRCLE YES OR NO UNDER BOTH CATEGORIES.

\begin{tabular}{|c|c|c|c|}
\hline \multicolumn{2}{|c|}{ DOES YOUR DISIRICT HAVE: } & \multicolumn{2}{|c|}{ DOBS YOUR BUILAING HAVE: } \\
\hline 44. & $\begin{array}{l}\text { A written polley concerning } \\
\text { dropouts? } \\
\text { yes no }\end{array}$ & yeg & no \\
\hline 45. & $\begin{array}{l}\text { A wrltten pollcy concerning } \\
\text { student attendance? } \\
\text { yes no }\end{array}$ & yes & no \\
\hline 46. & $\begin{array}{l}\text { At least one student health } \\
\text { center? } \\
\qquad \text { yes no }\end{array}$ & yes & no \\
\hline 47. & $\begin{array}{c}\text { Chlld care facllitles? } \\
\text { yes no }\end{array}$ & yes & no \\
\hline 48. & $\begin{array}{c}\text { Glfted and talented programs? } \\
\text { yes no }\end{array}$ & yes & no \\
\hline 49. & $\begin{array}{l}\text { Engllsh taught as a second } \\
\text { language? } \\
\qquad \text { yes }\end{array}$ & yes & no \\
\hline 50. & $\begin{array}{c}\text { Cooperat ive work programs } \\
\text { wlth the communlty? } \\
\text { yes no }\end{array}$ & yes & no \\
\hline 51. & $\begin{array}{c}\text { Parent effect lvenegs } \\
\text { tralning programs? } \\
\text { yes no }\end{array}$ & yes & no \\
\hline
\end{tabular}




\begin{tabular}{|c|c|c|}
\hline 52. & $\begin{array}{l}\text { Functloning interventlon } \\
\text { programs in the elementary } \\
\text { and mlddle schools for } \\
\text { prevention of later dropout? } \\
\text { yes no }\end{array}$ & \\
\hline 53. & $\begin{array}{c}\text { Separate bullding alternatlve } \\
\text { programs for at rlsk students? } \\
\text { yes no }\end{array}$ & \\
\hline 54. & & $\begin{array}{l}\text { Small-group advisorles started in the } \\
\text { ninth grade and maintalned through the } \\
\text { senlor year? } \\
\text { yes no }\end{array}$ \\
\hline 55. & & $\begin{array}{l}\text { Requlred } 11 \text { fe skllls/transltion } \\
\text { clagses for ninth graders? } \\
\text { yes no }\end{array}$ \\
\hline 56. & & $\begin{array}{l}\text { In-bullding al ternatlve progr ans? } \\
\text { yes no }\end{array}$ \\
\hline 57. & & $\begin{array}{l}\text { Vocatlonal programs? } \\
\text { yes no }\end{array}$ \\
\hline 58. & & $\begin{array}{l}\text { Honors courses? } \\
\text { yes no }\end{array}$ \\
\hline 59. & & $\begin{array}{l}\text { Monetary Incentlues for students? } \\
\text { yes no }\end{array}$ \\
\hline 60. & & $\begin{array}{c}\text { School unl forms? } \\
\text { yes no }\end{array}$ \\
\hline E1. & & $\begin{array}{l}\text { Orlentatlon programs for freehmen that } \\
\text { help them feel "bonded" to the school. } \\
\text { yes no }\end{array}$ \\
\hline
\end{tabular}


62. Of the Items listed in questions 44 through 61 , which do you think have been the most effectlve in reducing the number of students' dropping out in your school? Please rank those 11 sted below from 1 as the hlghest, ranking the top 10. If you have effectlve programs not mentloned above, please 11 st them below and Include them in the ranking.

Written Dist. dropout policy

Written Dlst. attendance policy

In-house progresslve discipllne

Heal th centers

Out-of-bldg. al ternat Ive proge ans

Child care

Gifted and talented

Cooperatlve work programs

School unl forms

Teaching English as a second language

Parent effectlveness training programs

Written blag. dropout policy

Written bldg. attendance policy

Small-group advisorles

Requlred llfe skllls class

in-bidg. alternatlve

programs

Vocatlonal programs

Honors courses

Monetary Incent!ves

Freshmen "bondlng" programs

other programs used in your school:

Your Interest and time in completIng this questlonnalre is greatly appreclated. Please return the form in the enclosed envelope. It you would like a sumnary of the results, please include your name and address here; the study should be completed by June, 1989. Thank you.

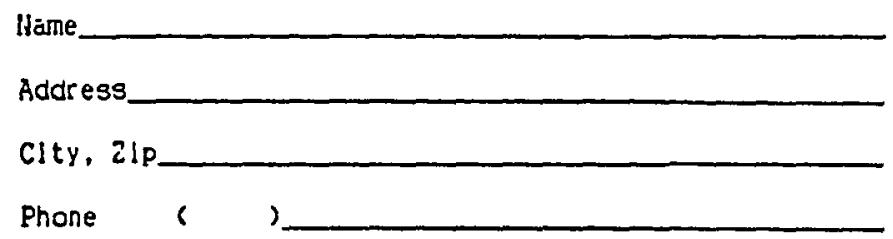

I would be wllllng to partlclpite in a followup Intervlew.

yes no 
APPENDIX C

SOUTHWEST WASHINGTON SURVEY TAKEN IN 1988 


\section{SECONDARY SCHOOL SURVEY \\ Clark, Cowlltz, Lewls, and Thurston Countles}

Name of High School responding

Count;

FOR BACH ITEY, PLEASE CHECX DNE CATEGORY WHICH BEST DLSCRIBES YOUR BUILDING.

1. The geographlc setting is mainly:

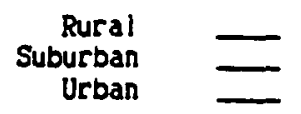

2. The current bullaing enrollment is:

$$
\begin{array}{r}
0-100 \\
101-200 \\
201-300 \\
301-400 \\
401-500
\end{array}
$$

$$
\begin{aligned}
& 501-600 \\
& 601-700 \\
& 701-800 \\
& 801-900 \\
& 901-1000
\end{aligned}
$$

If enrollment is over 1500, would you state the number here ..............

3. How many girls are currently encolled?

4. How many boys are currently enrolled?

5. What is the average number of students per classrocm, to the best of your knowledge?

$$
\begin{array}{r}
1-5 \\
6-10 \\
11-15
\end{array} \quad \begin{aligned}
& 16-20 \\
& 21-25 \\
& 26-30
\end{aligned} \quad \begin{aligned}
& 31-35 \\
& 36-40 \\
& \text { Over } 40
\end{aligned}-
$$

$1001-1100$

$1101-1200$

$1201-1300$

$1301-1400$

$1401-1500$

6. What is the per oupll expendlture for your district?

$$
\begin{aligned}
& \text { Under } \$ 2,500 \\
& \$ 2,500-\$ 3,000 \\
& \$ 3,000-\$ 3,500 \\
& \text { Over } \$ 3,500
\end{aligned}
$$

7. What is the average per caplta income for your dlstrict?

Under $\$ 5,000$

$\$ 5,000-\$ 10,000$

$\$ 10,000-\$ 15,000$

$\$ 15,000-\$ 20,000$

$\$ 20,000-\$ 25,000$

(over)

Over $\$ 25,000$

Over $\mathbf{3 2 5 , 0 0 0}$ 
PLEASE ANSWER THE FOLLOWING OUESTIONS TO THE BEST OP YOUR MNOULEDGE.

*If there is only one hlgh school In your distrlet, the Information for $t \theta$ and $\$ 9$ is already avallable. Please sklp $\$ 8$ and $\$ 9$ and go di rectly to 10 .

8. How many total ninth graders (elther In your bullding or that feed into your bullding) were enrolled in September, 1982?

Number of glrls?

Number of boys?

9. How many students graduated in 1986?

Number of girls?

Number of boys?

*10. To your best estimation, what is the raclal distrlbution of the student body population? (The percentages should add up to 100.)
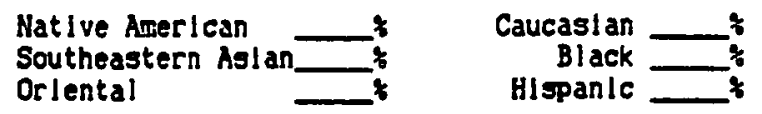

PLEASE CHECX THE POLLONING CUESTIONS BITHER YES OR NO.

YES NO

11. Does your distrlet have a wrltten pollcy statement regarding Graduatlon_Rates or Dropout_Rates?

12. Does your bullding have a written pollcy statement regarding Graduation Rates or Dropout Rateg?

13. Are nlnth graders Included If the hlgh school?

14. Would you like to recelve a copy of the data sumary when It is completed?

******************

Thank you for completing this questlonnalre. Although it is probably not one of the longest quest lonnalres you have completed, several of the questlons were not easlly answered. Your perslstence is oreatly appreclated! envelope.

$$
\text { When done, please return the form in the attached }
$$

